Check for updates

Cite this: Mater. Adv., 2020 1,292

Received 24th March 2020, Accepted 3rd May 2020

DOI: 10.1039/d0ma00128g

rsc.li/materials-advances

\title{
Challenges and approaches towards upscaling the assembly of hybrid perovskite solar cells
}

\begin{abstract}
Ahmed Esmail Shalan (iD ab
In recent times, the next-generation photovoltaic technologies have accepted perovskite solar cells (PSCs) as different auspicious candidates as a result of their persistently developing efficiencies, thus attracting significant attention from both the scientific and industrial societies. Even though PSCs are dignified toward the commercial world through the photovoltaic module scale, significant challenges confusing industrialization remain. The recent efficiency of the solution-processed PSCs has reached over $25 \%$ on a laboratory scale. However, a reproducible allocation to the upscaling techniques of these processes still requires a highly controllable perovskite film formation strategy. Different coating systems such as blade coating, slot-die coating and spray coating as well as printing pathways such as screen, inkjet, and gravure printing besides vacuum deposition and laser patterning methods have been widely used as the substitutions of spin coating towards scaling up PSCs with a large area. In the current review, we have reported the practical potential of PSCs, strategies, challenges, and approaches towards the scaling up of large-area PSC modules via different deposition techniques as well as functional materials for the device architecture.
\end{abstract}

\section{Introduction}

${ }^{a}$ BCMaterials-Basque Center for Materials, Applications and Nanostructures, Martina Casiano, UPV/EHU Science Park, Barrio Sarriena s/n, Leioa 48940, Spain. E-mail:a.shalan133@gmail.com,ahmed.shalan@bcmaterials.net;

Tel: +34946128811

${ }^{b}$ Central Metallurgical Research and Development Institute (CMRDI), P.O. Box 87, Helwan, Cairo 11421, Egypt

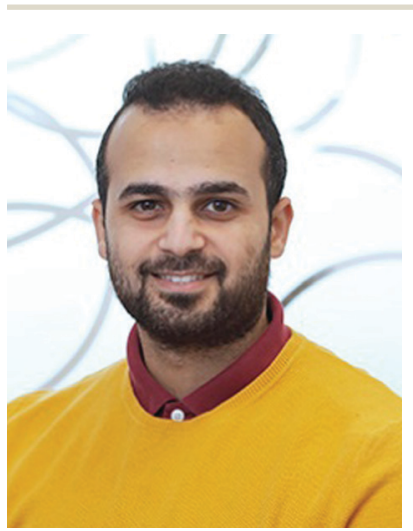

Ahmed Esmail Shalan
Ahmed Esmail Shalan is Juan de la Cierva Fellow at BCMaterials, Basque Center for Materials, Applications, and Nanostructures, Leioa, Spain. He obtained his BSc (2008) and MSc (2012) in Materials Science from Ain Shams University, Egypt and his $\mathrm{PhD}$ (2017) from Hokkaido University, Japan. He is Researcher at Central Metallurgical Research \& Development Institute (CMRDI), Egypt (on leave). He obtained several awards like Egyptian Academy Prize (2018), and fellowships like DAAD fellowship (i-MEETFAU), Germany (2013). His work has been summarized in more than 40 articles (with an $h$ index of 19), which reflects his interest in nanotechnology and materials science for energy and environmental applications.
Solar energy direction have been changed a lot by many researchers once the perovskite materials $\left(\mathrm{CH}_{3} \mathrm{NH}_{3} \mathrm{PbI}_{3}\right)$ investigated as a new light harvesting material for hybrid perovskite solar cells (PSCs). ${ }^{1}$ A power conversion efficiency (PCE) of $25.2 \%$ of these kinds of solar cells was certified in 2019, which is close to that of monocrystalline silicon cells. ${ }^{2}$ These perovskite materials have different features such as high absorption coefficient, ${ }^{3,4}$ high mobility, ${ }^{5-8}$ long balanced carrier diffusion length, ${ }^{7-10}$ and small exciton binding energy, ${ }^{11}$ which make them auspicious candidates for the fabrication of these new kinds of solar cells. Besides, there are several kinds of solar cell systems similar to organic photovoltaics, ${ }^{12}$ dye-sensitised solar cells $^{13-20}$ and perovskite cells, ${ }^{21-26}$ which intent to earn the benefit of the large-scale PSC modules with low fabrication cost. PSCs with a large active area of $1 \mathrm{~cm}^{2}$ have only achieved almost $20 \%$ in the past few years, which confirms that the upscaling of the normal active area of $0.1 \mathrm{~cm}^{2}$ of these kinds of cells is mandatory for the future modules of these kinds of cells as the active area is considered as an important factor for the detection of the net efficiency. ${ }^{27}$ The transformation of the perovskite photovoltaic technology in the sequence of "lab-tofab" becomes a trend towards scaling up PSCs. ${ }^{28}$ In fact, the active area, stability and cost of the proposed materials can be possible drawbacks for the commercial upscaling of PSCs. The active area can be affected by the series resistance of the electrodes, which results from the quality of the assembled 
layers via coverage and uniformity and decreases the net efficiency of the fabricated modules. ${ }^{29,30}$ Additionally, temperature, illumination and humidity may influence the assembled module stability deemed as a significant shortcoming of PSCs. ${ }^{31-33}$ Furthermore, to overcome the drawbacks encountered while using the same deposition techniques of small-area cells for upscaling, several production methodologies such as spin coating, ${ }^{34}$ blade coating, ${ }^{35}$ slot-die coating, ${ }^{36}$ and vacuum evaporation $^{37}$ have been recognised to achieve large-scale and improved eminent perovskite films. Galagan and co-workers aimed to optimize the assembled modules by finding the match for active area size and PCE by studying the standard dimensions of large-area PSCs to attain good uniformity and reproducibility over the module area. ${ }^{38-42}$ In addition, they confirmed their experimental data using a theoretical DC simulation in order to get an appropriate matching between transparency and substrate sheet resistance. Herein, in this review, the advancements matters approved on effective largearea perovskite solar modules from the view of several fabrication technique, with studying the strategies and the challenges exist for this purpose will be covered and discussed.

\section{Structural design of devices}

\subsection{Perovskite solar cell architectures: configurations and technical challenges}

Perovskite solar cell (PSC) device configurations are mainly classified into two groups: mesoporous and planar structures with three different types: mesoporous $n-i-p$, planar $n-i-p$ and planar p-i-n structures (Fig. 1).

The typical mesoporous $n-i-p$ (PSC) architecture (Fig. 1a) includes perovskite materials that are partially or completely infiltrated in an electron transport layer (ETL) scaffold with nanoscale pores, leading to an intermixed layer. After that, the hole transport layer (HTL) is deposited on the perovskite layer, and then the structure of the assembled device is completed through evaporation of the top electrode. The photocurrentvoltage $(J-V)$ hysteresis phenomenon in PSCs can be suppressed by enhancing charge separation using mesoporous materials. ${ }^{43}$ The planar n-i-p (PSC) architecture (Fig. 1b), which has recently given high-efficiency performance with little hysteresis, is encompassed with a compact ETL layer that attaches directly to the perovskite layer without using any mesoporous layer. ${ }^{4-46}$ In the current status, the existence of mesoporous materials, and sometimes HTL, in the n-i-p cell structure is not favourable for scaling up modules, as it will increase the fabrication steps. ${ }^{47}$ Additionally, the inverted structure, $\mathrm{p}-\mathrm{i}-\mathrm{n}$ architecture (Fig. 1c), which is normally assembled with a planar structure, is coming from the inversion in the carrier extraction layers compared to the $\mathrm{n}-\mathrm{i}-\mathrm{p}$ configuration.

\subsection{Perovskite solar module structures}

Obviously, due to the resistance loss above the conducting electrode that may appear as a long transference expanse, the upscaling of perovskite solar modules will not be easy to attain via fabrication of a single PSC on a large-area substrate. Additionally, combining minor sub-cells with a series of interconnection areas, which act as the main aspect toward power loss in solar modules, can diminish the resistance loss to form a stable module (Fig. 2a). ${ }^{49}$ The geometric fill factor (GFF) can define the photoactive area and the total area of the module ratio, and it was found that the calculation of GFF becomes essential to detect the accurate module efficiency as the module efficiency is proportionally related to the active area as well as GFF. ${ }^{50}$ In addition, there are several steps involved in the fabrication of perovskite solar modules (PSMs). ${ }^{51}$

Furthermore, the assembled assimilated perovskite solar module design with the altered constituent arrangement is shown in Fig. 2b. It is important that the so-called balance of module (BOM) is used to protect the fabricated modules from water-induced degradation, ${ }^{52}$ through its components including glass plates, a sealant, a lamination film, an edge-sealing frame, a junction-box, and wiring. ${ }^{53-55}$ Ultimately, the upscaling fabrication of large-area cells can be summarized via assembling highquality perovskite cells, combining those cells to form a module and, finally, integrating the modules into a panel (Fig. 2c).

\subsection{Scalable solution deposition methods}

Spin coating as well as other several deposition and printing methods such as blade coating, slot-die coating, spray coating, inkjet printing and screen-printing have been widely used in the preparation of different layers for solar cell composition. The spin coating technique is considered as the traditional way (a)

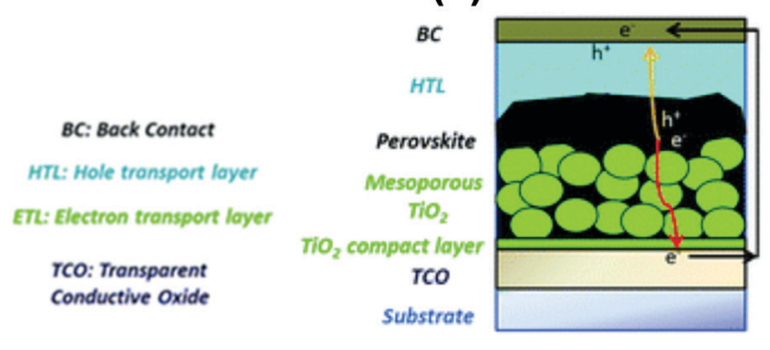

(b)

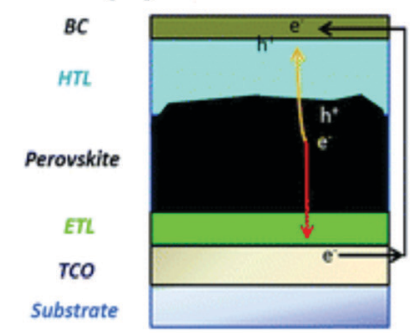

(c)

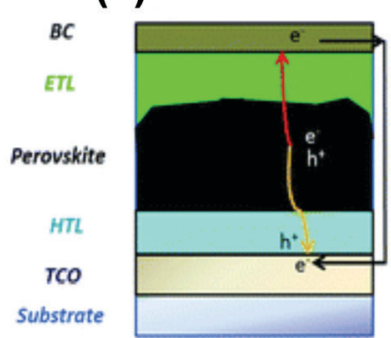

Fig. 1 Perovskite solar cell architectures: (a) n-type $\mathrm{TiO}_{2}$ mesoporous-based; (b) planar " $n-\mathrm{i}-\mathrm{p}$ "; (c) planar "p-i-n". Illumination occurs from the substrate side. In all these cases, the substrate can be either a glass or polymer foil. Reproduced with permission from ref. 48 . Copyright $($ C 2017 The Royal Society of Chemistry. 
(a)
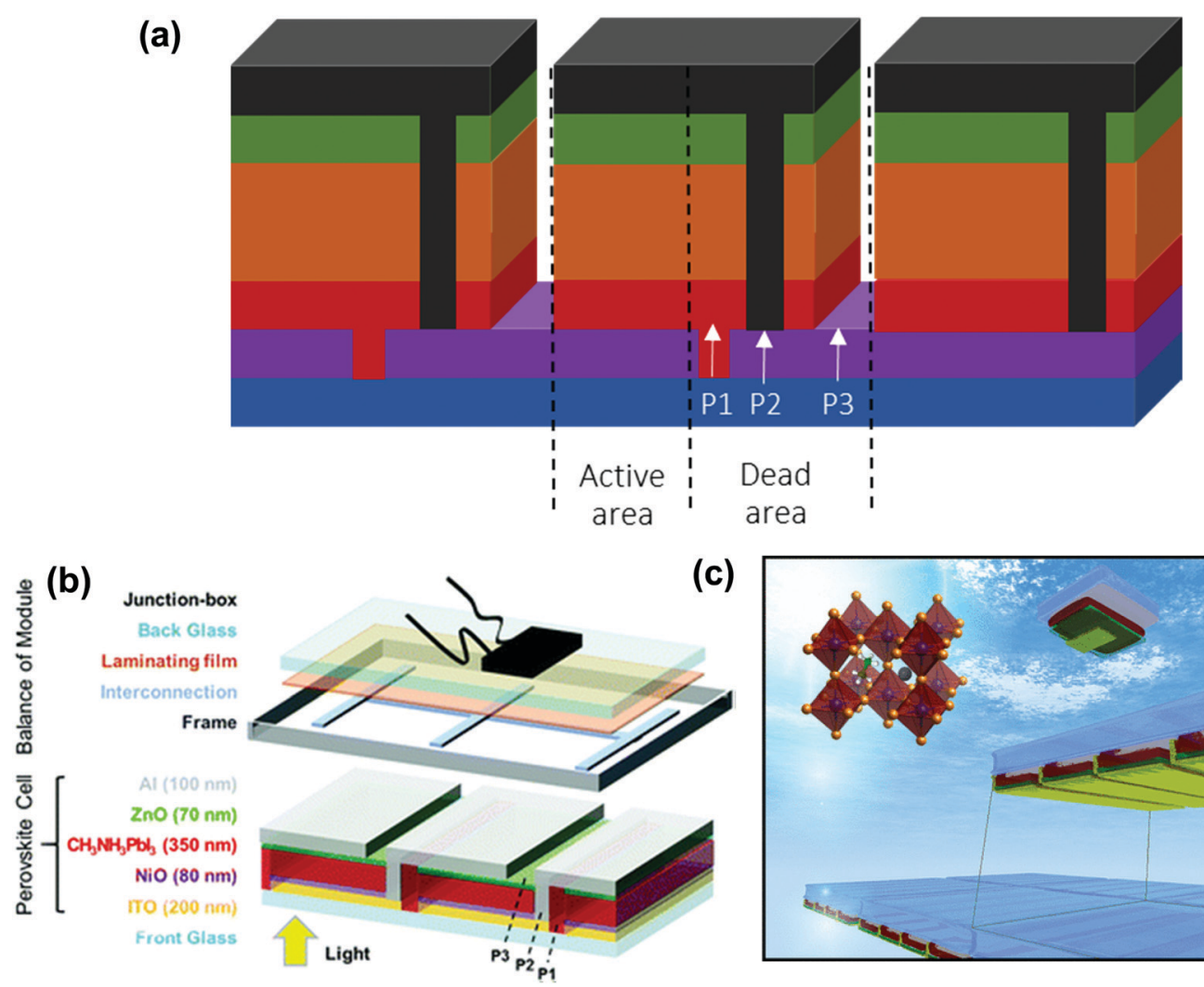

(c)

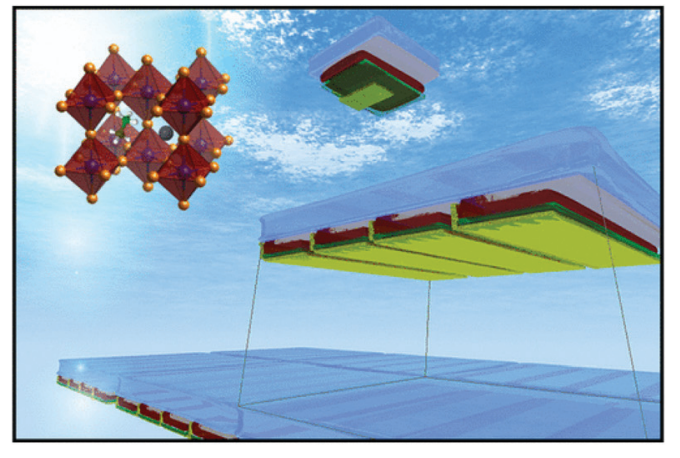

Fig. 2 Perovskite solar module architectures. (a) Interconnection of a perovskite module fabricated by typical scribing processes for thin-film solar modules. The P1 scribe separates the bottom TCO substrate, the P2 scribe provides a channel to connect the top contact of one cell to the bottom contact of the next cell to form an interconnection, and the P3 scribe isolates the top metal contact between neighbouring cells, to form cells that can be integrated into a module. (b) Structure of a monolithically integrated perovskite solar module design with different configuration layers. Reproduced with permission from ref. 55. Copyright (C) 2017 The Royal Society of Chemistry. (c) Up-scaling laboratory-scale perovskite solar cells to modules and panels. Reproduced with permission from ref. 51. Copyright (C) 2017 American Chemical Society.

for perovskite thin-film deposition. The precursor solution of perovskite materials used to fabricate the perovskite films in spin coating as well as scalable deposition methods consists of organic and lead halides, which first liquefied in organic solvents like $N, N$-dimethylformamide (DMF), dimethyl sulfoxide (DMSO) and $\gamma$-butyrolactone (GBL). Additionally, modules are made up via spin coating on a substrate area of about $10 \mathrm{~cm} \times$ $10 \mathrm{~cm}$ but with an extensively lower PCE than their corresponding smaller area items. ${ }^{56}$ The advantages such as thinning and smoothing gained from the spin coating method for low-area film deposition are challenging to be obtained in scalable deposition processes. Therefore, in order to fabricate PSMs by controlling the assembled films in different positions, many factors should be understandable and different other pathways must be designed for increasing the active area of PSCs. Herein, different scalable solution deposition methods and their benefits for PSC and PSM improvement are briefly studied and compared.

\subsection{Coating techniques for perovskite photovoltaics}

Besides spin coating, as forerunners for perovskite film deposition on a laboratory scale, several coating techniques are introduced in order to pave the way for upscaling PSCs and obtain PSMs by controlling the quality of perovskite films deposited above large areas with high uniform layers with good crystallinity and morphology. As meticulous below, some general competing coating methodologies will be discussed to gain deep knowledge on how these techniques are used for the fabrication of PSCs and going further on the way to upscaling PSMs to accomplish the methodological necessities for industrial approach of perovskite thin films for cells and modules.

2.4.1. Spin coating. The spin coating method is considered as the common pathway to obtain large-area, highly uniform and pinhole-free perovskite films for laboratory-scale PSCs, which paves the way for the use of the spin coating technique to attain stable perovskite solar modules with large area and high efficiency as well as stability. ${ }^{57}$ The benefits and advantages behind that exhausting technique of deposition are to accomplish different uniform layers with high film thickness and high reproducibility, which achieved different controllable parameters with ink formulation. In addition, the top efficiency recorded for the small-laboratory-scale cells fabricated via the spin coating pathway, with an active area of almost $0.1 \mathrm{~cm}^{2}$, was higher than that of the others with a large area with an active area $\geq 1 \mathrm{~cm}^{2}{ }^{42}$ The diminution in efficiency, which is considered as one of the most important disadvantages of this 
(a)

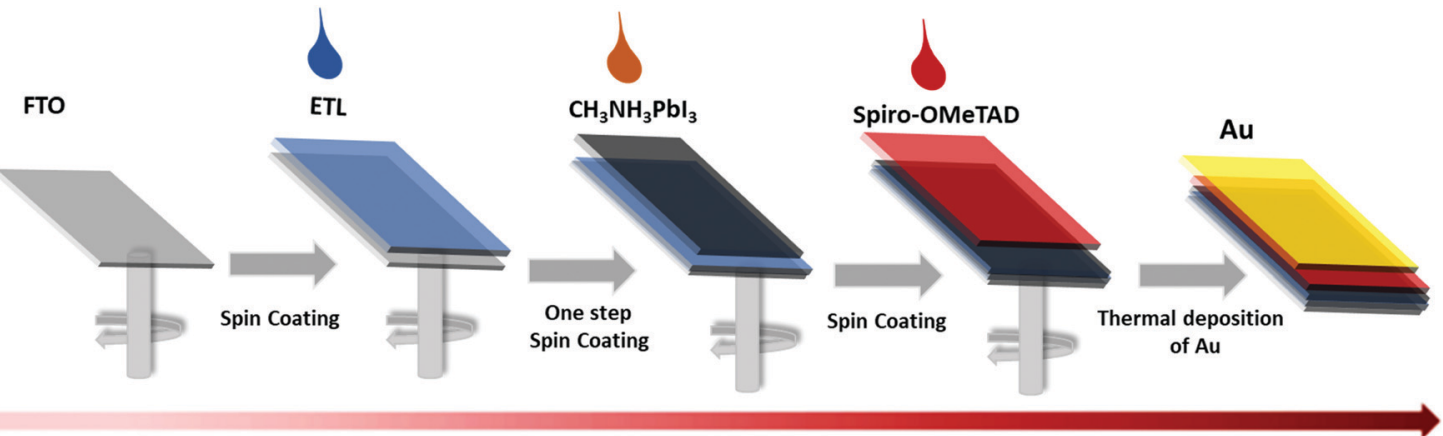

(b)

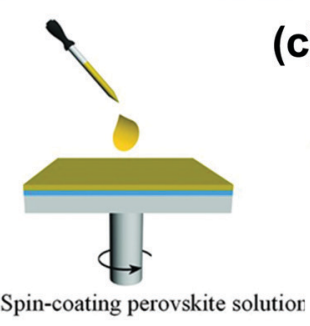

(e)

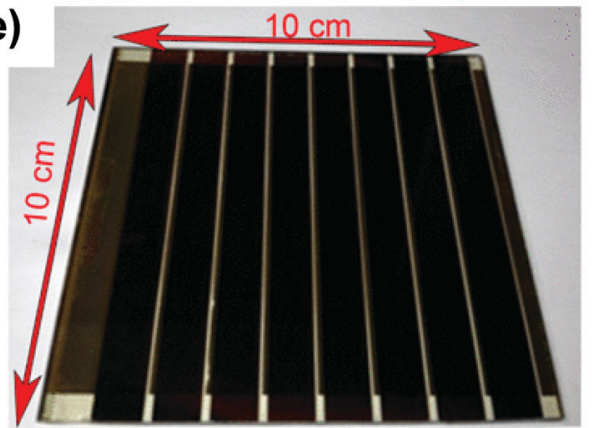

(c)

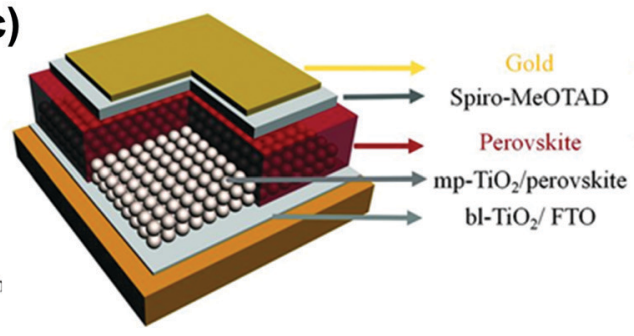

(f)

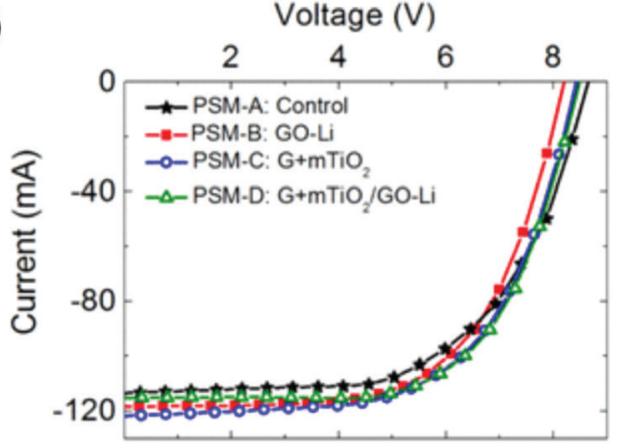

Fig. 3 Perovskite film deposition and device structure. (a) Schematic of perovskite solar devices step by step. (b) Schematic showing the spin coating of the perovskite solution on the substrate. (c) Schematic of the perovskite solar cell configuration, where a smooth and compact perovskite capping layer fully covers the mesoporous $\mathrm{TiO}_{2}$ layer $\left(\mathrm{mp}-\mathrm{TiO}_{2}\right)$ infiltrated with perovskites. (d) A high-resolution cross-sectional SEM image of a complete perovskite solar cell with large area fabricated by the spin coating technique. (b-d) Reproduced with permission from ref. 61 . Copyright $\mathbb{C}$ 2016 SpringerNature. (e) Photograph of the large-area perovskite solar module $\left(50 \mathrm{~cm}^{2}\right.$ active area). (f) Current-voltage (I-V) characteristics of tested modules (i.e., PSM-A, PSM-B, PSM-C, and PSM-D). All the $I-V$ measurements refer to the encapsulated devices. (e and f) Reproduced with permission from ref. 62 . Copyright $\mathbb{C}$ 2016 American Chemical Society.

technique, comes from the difficulty in controlling the deposition of different layers via spin coating in case of the large area, which affected the uniformity as well as the crystallinity of the assembled layers. ${ }^{58,59}$ Furthermore, Yang et al. ${ }^{59}$ attained a PCE of $16.3 \%$ with a stabilized output of $15.6 \%$ in $\mathrm{CH}_{3} \mathrm{NH}_{3} \mathrm{PbI}_{3}$ perovskite-based cells on an active area of $1.2 \mathrm{~cm}^{2}$. In addition, with a spin-coated perovskite layer, Qiu et al. ${ }^{60}$ apprehended a module with a PCE of $13.6 \%$ over an orifice area of $4 \mathrm{~cm}^{2}$.

The fabrication of different layers of perovskite cells or modules by the spin coating technique is illustrated in Fig. 3a. In addition, to assemble perovskite solar cells, the conductive electrode (FTO) was etched to obtain the anticipated pattern, and then an ETL of $\mathrm{TiO}_{2}$ was deposited via the spin coating pathway. After that, the perovskite layer and the HTL were deposited layer by layer above $\mathrm{TiO}_{2}$ by the spin coating technique and finally the cell was obtained by thermal evaporation of $\mathrm{Au}$ on the top. The schematic of the spin coating process of the perovskite solution on the substrate surface is shown in Fig. 3b. Either the perovskite cells or modules can be fabricated by the spin coating technique, which considers being one of the essential pathways to deposit the main constituent layers. ${ }^{61}$ Additionally, the schematic design of the perovskite solar cell arrangement, where a smooth and compact perovskite capping layer fully covers the mesoporous $\mathrm{TiO}_{2}$ layer $\left(\mathrm{mp}-\mathrm{TiO}_{2}\right)$ subverted with perovskites, is shown in Fig. 3c. The mesoscopicplanar bilayer device architecture with a cross-sectional SEM image is illustrated in Fig. 3d to affirm the alteration in morphology between films in the fabricated cell. ${ }^{61}$

One of the latest studies that concern about the production of perovskite modules with large active area by the spin coating technique was done by Di Carlo et al. ${ }^{62}$ They established largearea perovskite solar modules (PSMs), assembled on a $10 \times$ $10 \mathrm{~cm}^{2}$ substrate area, comprising eight series of joined PSCs (active area $6.32 \mathrm{~cm}^{2}$ ), with different interfaces and an overall 
active area of $50.56 \mathrm{~cm}^{2}$ (Fig. 3e), with $I-V$ characteristics (Fig. 3f), paving the way for the industrial exploitation of graphene/ perovskite solar cells (PSCs).

2.4.2. Doctor blade coating (blade coating). The blade coating technique (Fig. 4) is a simple and cheap printing choice, considered as a convenient pathway for incessant construction with roll-to-roll operations, leading to fully printable devices on both glass and flexible substrates, wherein the blade is immobile and flexible substrates on a roller are in motion to attain PCE $>19 \% .{ }^{63}$ Mallajosyula et al. ${ }^{64}$ reported deposition of perovskite island films with large grain sizes via one-step blade coating above large-area substrates. Furthermore, one of the advantages of the blade coating technique while using continuous roll-to-roll deposition is that the ink waste is substantially reduced compared with the spin coating technique, which resulted in the deposition of homogeneous thin films with a controllable thickness.

As any other technique that has advantages and disadvantages, the blade coating technique can show some disadvantages which come from controlling the gap between the blade and the substrate. The disadvantages can be overcome by monitoring the blade geometry as well as its speed, in addition to the viscosity of the ink and the substrate wettability.

The main target to obtain either small-area PSCs or largearea PSMs is to assemble high-quality large-area perovskite layers that is secure from the doctor blade coating technique as illustrated in Fig. $4 .^{65}$ To follow the procedure for film assembly via the blade coating method, a solution of appropriate concentration is added to the substrate and the doctor blade is moved at an optimized speed of $1.0 \mathrm{~cm} \mathrm{~s}^{-1}$ to form a contact line (Fig. 4a and b). ${ }^{65}$ The aggrandize structure of contact line is shown in Fig. $4 c .{ }^{66}$ By reason of the in situ thermal annealing of the substrate, the solvent evaporates very rapidly and forms the perovskite film (Fig. $4 \mathrm{~d}$ and e). ${ }^{65}$
2.4.3. Inkjet printing and slot-die coating. Inkjet printing in addition to slot-die coating is considered as an auspicious method to assemble and scale up perovskite solar modules manufactured on a large scale. On one hand, in inkjet printing, nozzles, with droplet size control, are the source to disperse the precursor ink (Fig. 5a). Different studies confirm the suitability of inkjet method to fabricate both small- and large-area solar cells with respect to the printing speed and device structure to get large areas of perovskite modules, which is considered as an important advantage of that technique. ${ }^{67}$ On the other hand, slot-die coating (Fig. 5b) is similar to blade coating and uses a reservoir of ink with a thin slit to spray ink over the substrate that is also considered as an advantage for both techniques. ${ }^{68}$

Comparing slot-die coating with other deposition methods like blade ones, although it need more amount of inks, which is considered as a disadvantage of that technique, it shows better yield and reproducibility for the fabricated layers with uniform surface, good morphology and crystallinity. ${ }^{69-71}$ Inkjet printing as well as slot-die is an auspicious printing pathway to develop the assembly of PSCs with a scale up range for up to $51 \mathrm{~cm}^{2}$ active area, and can be predominantly significant even for roll-to-roll manufacturing in the future. ${ }^{72-75}$ The cross-section SEM of the fabricated perovskite solar cell based on $\mathrm{TiO}_{2}$ nanoparticles, by the coating technique, is illustrated in Fig. 5 c. $^{76}$

Scalable fabrication of PSCs depending on $\mathrm{TiO}_{2}$ nanoparticles deposited by inkjet-printing as well as slot-die methods exhibits high PCE (measured in backward and forward directions) compared to the samples attained by the spin coating technique as shown in Fig. 5d and f. Likewise, PCE at a persistent voltage up to the maximum power point (MPP) was checked for both devices (Fig. 5e and g). ${ }^{72}$ The good results obtained for the different cells with two techniques confirm the possibility to use these techniques for large-scale fabrication and can open up a new pathway for all inkjet (or slot-die)-printed PSCs. ${ }^{76-79}$

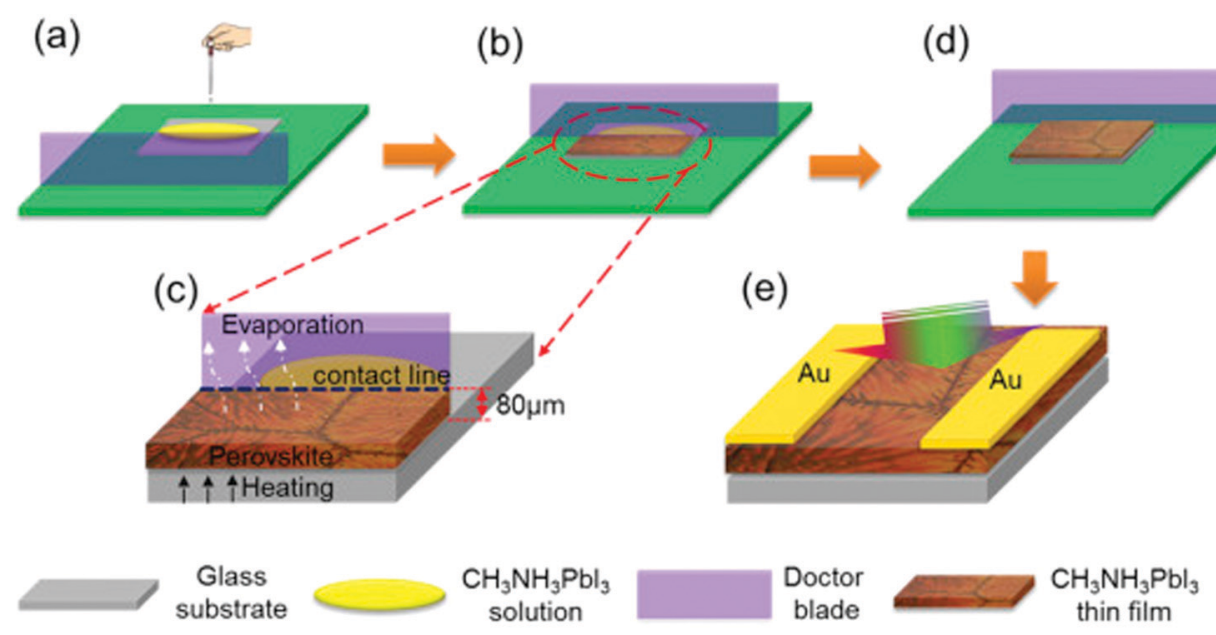

Fig. 4 Schematic of in situ doctor blade coating technique for fabricating $\mathrm{CH}_{3} \mathrm{NH}_{3} \mathrm{Pbl}_{3}$ films. (a) $\mathrm{CH}_{3} \mathrm{NH}_{3} \mathrm{Pbl}_{3}$ solution $\left(550 \mathrm{mg} \mathrm{ml}^{-1}\right.$ ) is dropped before the doctor blade closes the substrate. (b) $\mathrm{CH}_{3} \mathrm{NH}_{3} \mathrm{Pbl}_{3}$ crystal nucleate and growth during doctor blade coating. (c) Magnified schematic in (b). (d) $\mathrm{CH}_{3} \mathrm{NH}_{3} \mathrm{Pbl}_{3}$ crystal film is growing with the moving of doctor blade and a large-area $\mathrm{CH}_{3} \mathrm{NH}_{3} \mathrm{Pbl}_{3}$ film can be formed on the substrate. The substrate is in situ heated to $100-140{ }^{\circ} \mathrm{C}$. The spacing between the doctor blade and the substrate is $80 \mu \mathrm{m}$. (e) Schematic of a $\mathrm{CH}_{3} \mathrm{NH}_{3} \mathrm{Pbl} \mathrm{Pb}_{3}$ photodetector fabricated via doctor blade coating. The illumination light source irradiates from the front side of electrodes. Reproduced with permission from ref. 65 . Copyright (C) 2017 Elsevier. 
(a)

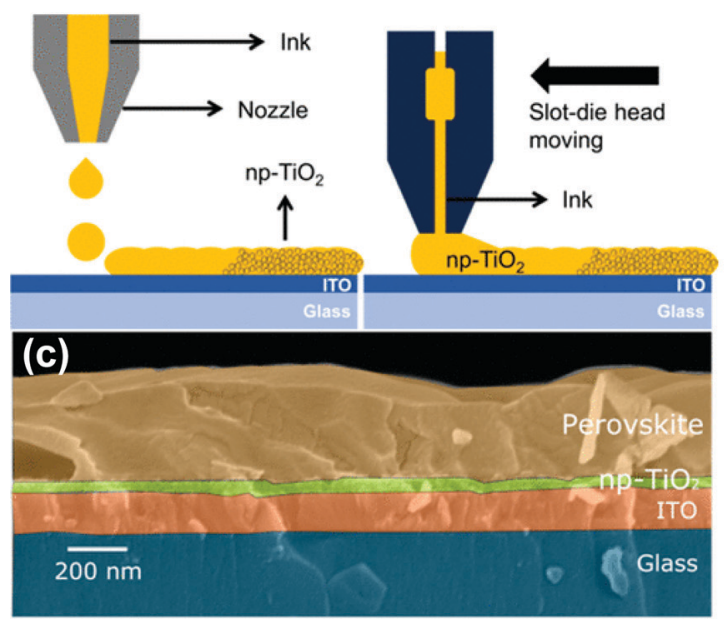

(d)

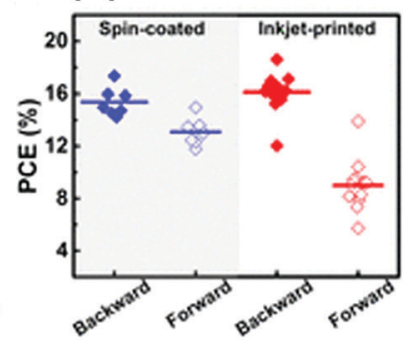

(f)

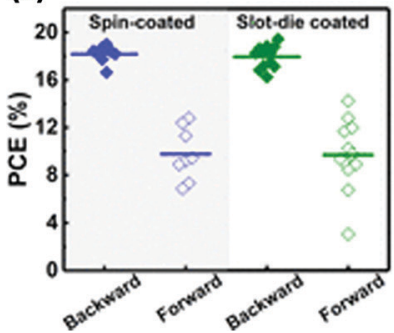

(e)

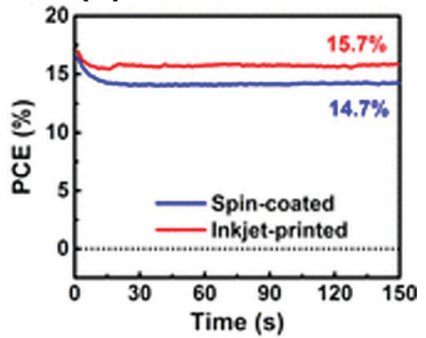

(g)

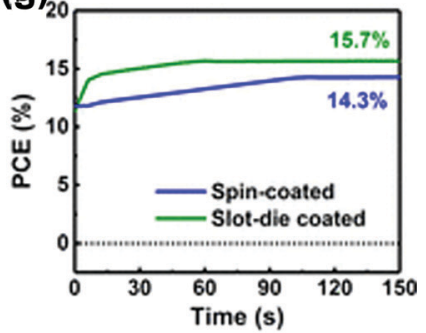

Fig. 5 Schematic of (a) inkjet printing and (b) slot-die coating of the $\mathrm{np}-\mathrm{TiO}_{2} \mathrm{ETL}$ is shown with the respective power conversion efficiencies of perovskite solar cells, fabricated on top of these layers in panels (d) and (f). (c) The cross-section SEM of the assembled perovskite solar cell. PCEs measured at a constant voltage near the maximum power point under AM1.5G illumination are represented in panel (e) and MPP tracking in panel (g) for $150 \mathrm{~s}$. Blue, red, and green represent PCEs of PSCs fabricated with spin-coated, inkjet-printed, and slot-die-coated np-TiO 2 ETL, respectively. Reproduced with permission from ref. 76. Copyright (C) 2018 American Chemical Society.

2.4.4. Spray coating. In different spray coating types, highquality films are obtained using a nozzle that intersperses tiny liquid droplets above substrates (Fig. 6a). ${ }^{80-82}$ In order to improve the spray-coated technique for PSC fabrication, Barrows et al. consummated the first study in 2014, showing an efficiency of $11.1 \%$ for the assembled cells. ${ }^{83}$ Several parameters, which affect the deposition method and are considered as a necessary factor for the realization of the absorber layer, such as substrate temperature, volatility of the coating solvent and post annealing temperatures were studied. ${ }^{84-86}$ In 2016, and for the first time, Das et al. showed the potential to fabricate PSCs on flexible substrates via roll-to-roll processing with an efficiency of almost $8.1 \%$, through spray-coated perovskite absorbers. ${ }^{85}$ Later, using two-step spray coating method, Hunag et al. succeeded to increase the homogeneity of the absorber deposition and enhance the spray-coated PSCs' net PCE to $16.0 \% .{ }^{87}$ Then, the highest PCE for spray-coated PSCs was reported to be $18.3 \%$ by the study of Heo et al., via optimizing the solvents' boiling point for governing the solvent evaporation and doing different characterizations of the assembled cells (Fig. 6b-d).$^{88}$ As a result of the most studies concerned about the spray coating technique, the assembling of $100 \mathrm{~cm}^{2}$ large $\mathrm{PV}$ modules via $40 \mathrm{~cm}^{2}$ active area and the comprehended PCE of the fabricated modules was almost $15.5 \% .^{88}$

In summary, to upscale the perovskite thin-film layers, spray coating is considered as an appropriate pathway towards that achievement. Diverse parameters like precursor, solvents,

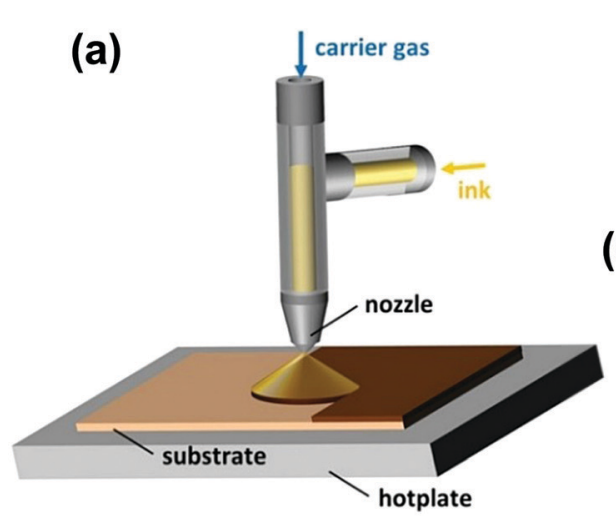

(b)

(c) $n$
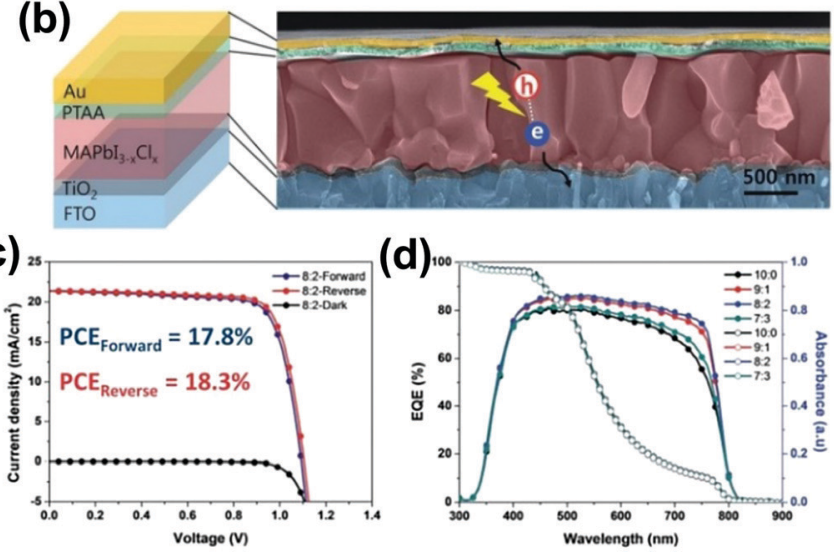

(d) 100

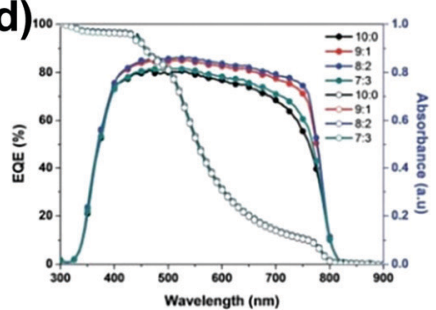

Fig. 6 Spray coating. (a) Schematic of the spray coating process. (b) SEM cross-sectional image of a high-quality spray-coated MAPbl${ }_{3-x} \mathrm{Cl}_{x}$ perovskite absorber. (c) PCEs up to $18.3 \%$ in reverse $J-V$ characteristics and (d) high external quantum efficiency (EQE) were achieved, which is a result of a careful solvent engineering of the spray process. Reproduced with permission from ref. 91. Copyright (C) 2019 WILEY-VCH. 
nozzle spray angle, the scanning speed, and the flow rate considered as advantages of that technique should be controlled for an attainable extraordinary throughput assembly and controlling the quality of perovskite thin films. ${ }^{89-91}$

\subsection{Printing techniques for perovskite photovoltaics}

In addition to the different coating techniques used to assemble both perovskite solar cells and perovskite solar modules, there are several printing and pattering techniques that illustrate effective potential toward attaining cells as well as modules in a good manner. The several printing pathways are presented to pave the way for upscaling PSCs and obtain PSMs controlling the quality of perovskite films deposited above large areas with a high uniform layer with good crystallinity and morphology. In the next section, some general competing printing methodologies will be discussed to gain deep knowledge on how these techniques are used for the fabrication of PSCs and going further on the way to upscaling PSMs to accomplish the methodological necessities for industrial approach of perovskite thin-films for cells and modules.

2.5.1. Screen printing. In screen-printing, the technique is dependent on holding the patterned mesh screen and transfer ink to the substrate. For these kinds of printing techniques, it is possible to attain fully printed PSCs with improvement of mesoporous layers to fabricate stable and enhanced devices. ${ }^{92-95}$ In 2017, Han et al. succeeded in fabricating and studying perovskite solar modules (PSMs) with the configuration structure of $\mathrm{FTO} /$ compact-TiO ${ }_{2} /\left(\right.$ meso- $\mathrm{TiO}_{2} / \mathrm{meso}^{-} \mathrm{ZrO}_{2} /$ meso-carbon)/perovskite, ${ }^{96,97}$ with a $100 \mathrm{~cm}^{2}$ substrate and an active area of $49 \mathrm{~cm}^{2}$, by the screen-printing technique by connecting 10 subcells serially in monolithic architectures to allow reproducible production. The module fabrication and architecture were presented schematically and as image (Fig. 7a and b). ${ }^{98}$ In addition, the energy level diagram of the fabricated devices, with barriers, to block the recombination of electrons with holes is shown in Fig. 7c. It can been noticed that, when the light illuminates, charge separation occurred as the electrons are transferred in the electron transport layer (ETL) direction and the holes directed to the hole transport layer (HTL) position, to $\mathrm{TiO}_{2}$ and carbon, respectively, and after that to the electrode. ${ }^{98}$ Along these lines, the disconnected carriers can be transported via serially connected PSMs as shown in Fig. 7d, after that, they are extracted to the external circuit. ${ }^{98}$

For the future prospects of that technique, most of the assembled devices exhibit up to $10 \%$ efficiency as well as long-term stability, which is considered as an advantage and also confirms the possibility of achieving the fully printable perovskite solar modules and put that kind of upscaling in the roadmap to efficacious commercialization of perovskite solar cells. ${ }^{99-101}$ A fully printable perovskite solar panel with $7 \mathrm{~m}^{2}$ area was fabricated as a first step in the direction of practical photovoltaic tender, as shown in Fig. 7e. Finally, each of the $1 \mathrm{~m}^{2}$ panels was accumulated via 96 PSMs and controlled modules with several numbers of sub cells. The assembled modules can be enhanced via an emerging auto production line, permitting incessant and manageable assembling process of the module (Fig. $7 \mathrm{f}$ ). ${ }^{98}$
2.5.2. Laser pattering. Laser system processing purposes to pattern or remove each layer in the perovskite cell configuration and avert any damage happening to the conductive (TCO) substrate. ${ }^{102}$ Spyropoulos et al. fabricated the perovskite solar modules by a laser pattering method which effectively suppress the hysteresis. ${ }^{103}$ Fig. $8 \mathrm{a}$ and b illustrate the schematic diagram as well as the cross-section SEM of the fabricated module with different layers. The $J-V$ performances of perovskite solar cells determined by the evaporation method, laminated contacts and the consistent perovskite module are obtained from Fig. 8c. ${ }^{103}$ Use of a laminated electrode in that study confirmed that the average efficiency is decreased owing to the loss of $J_{\mathrm{sc}}$ and FF by $11 \%$, which is matching to the previous studies, while $V_{\text {oc }}$ remains almost unchanged due to the optical interference gained via the EQE spectra for wavelengths $>550 \mathrm{~nm} \cdot{ }^{104-107}$ Outstandingly, the top electrode roll lamination was originally established to adapt as working thin-films for PSC and PSM technologies, which opens up a completely novel opportunity for the economic assembly of organic and hybrid electronic utilizations. ${ }^{103-105}$

2.5.3. Roll-to-roll (R2R) compatible deposition. R2R, with compatible parameters to different printing techniques, has been investigated to fabricate large-scale, low-cost devices and modules with high reproducibility. ${ }^{108-113}$ The material (A), chemical (B), and process (C) engineering indispensable to accomplish scaled-up PSC manufacture are delineated in Fig. 9. Bromide and formamidinium (FA), as perovskite materials (Fig. 9a), have been magnificently amalgamated inside the $\mathrm{CH}_{3} \mathrm{NH}_{3} \mathrm{PbI}_{3}$ lattice to alleviate $J-V$ hysteresis ${ }^{114}$ and eradicate fundamental thermodynamic instability. ${ }^{115}$

Through the R2R coating pathway and to optimize the $\mathrm{CH}_{3} \mathrm{NH}_{3} \mathrm{PbI}_{3}$ growth and obtain module-scale PSCs, different parameters of perovskite compositional engineering such as the microstructure and composition are considered as essential steps in that study (Fig. 9b). ${ }^{116}$ The extreme operative approach to regulate development thus turn out to be tuning the thermodynamics driving advance over and done with precursor solution composition, ${ }^{117}$ chemistry of the surface on which progression happens, ${ }^{118}$ annealing environments, and atmosphere in the course of progress. ${ }^{119,120}$ Solution additives and solvent engineering possibly will affect the morphology and film quality, which create interface adaptation as significant contemplation in scale-up notwithstanding the challenge of film deposition by the R2R pathway. ${ }^{120}$

Furthermore, the piercing restrictions to PSC market prospective may come from thermal and ambient instabilities, which push the impending price as well as flexible PSCs to be enhanced towards the technology's existing capability intended for commercialization (Fig. 9c). ${ }^{116}$

\subsection{Large-area fabrication techniques for modules}

Numerous techniques such as chemical vapour deposition (CVD), vapour-assisted sequential processing and vacuumsolid reaction (VSR) considered as promising pathways compared to the other above-mentioned deposition techniques were used to fabricate solar modules with large area and long-term stability. ${ }^{121}$ 
(a)

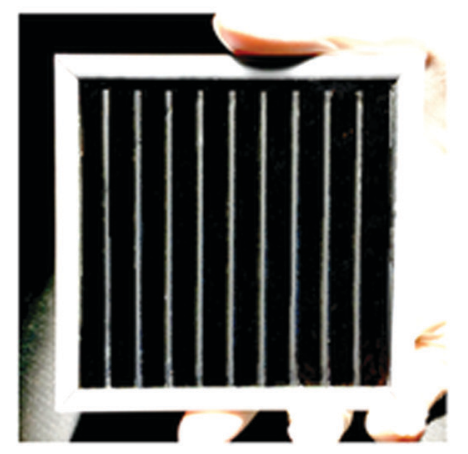

(c)

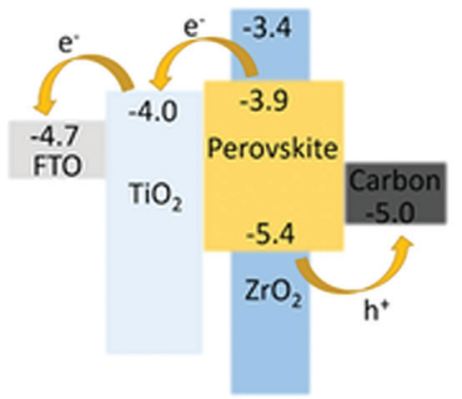

(b)

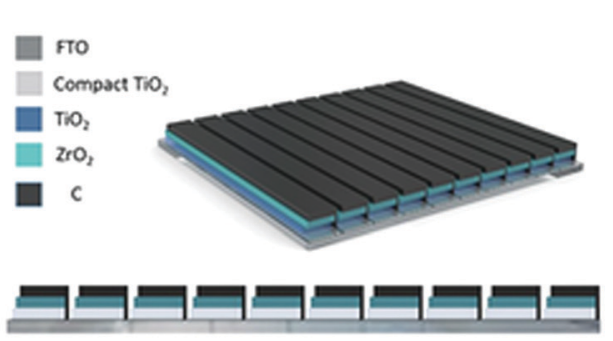

(d)

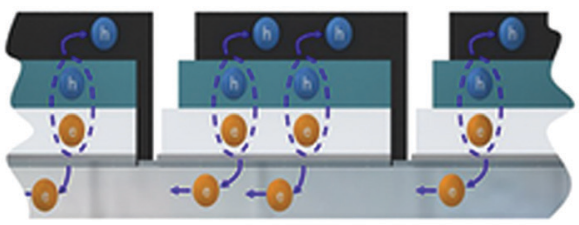

(e)

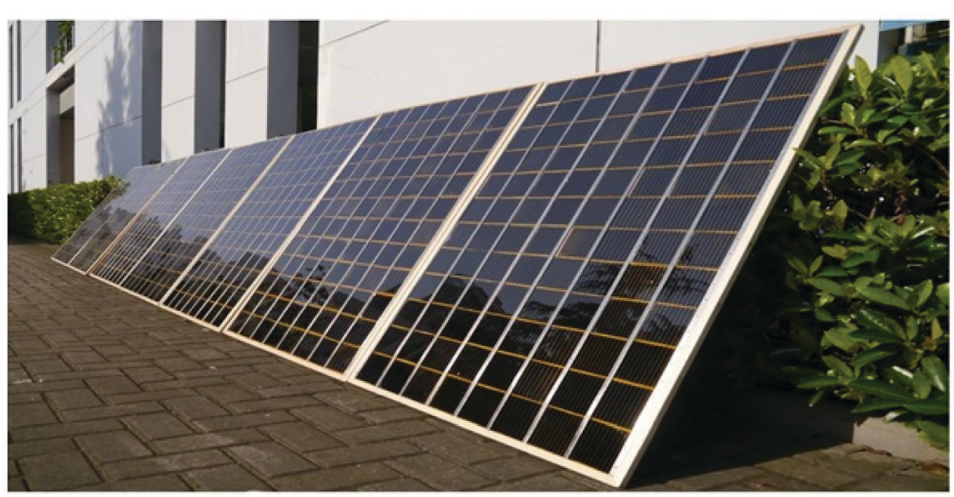

(f)

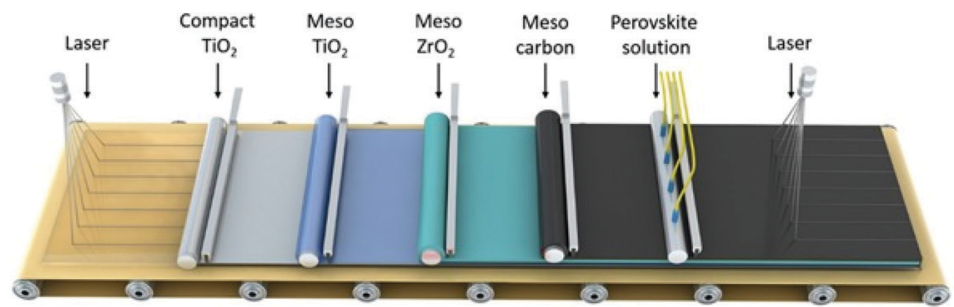

Fig. 7 (a) Image of a monolithic printable PSM with 10 subcells. (b) The monolithic interconnection scheme of the module. (c) Energy level diagrams of the hole-conductor-free printable PSC. (d) Schematic of the electron and hole separation on a serially connected PSM. (e) Image of $7 \mathrm{~m}^{2}$ printable perovskite solar panels. (f) Schematic of the proposed production line of PSMs. Reproduced with permission from ref. 98. Copyright (C) 2017 WILEY-VCH.

In order to attain perovskite modules with high efficiency and long-term stability, different parameters should be considered like the post annealing process to get homogeneous substrates with large crystals and pinhole free surface. ${ }^{122}$ Most of the vacuum deposition methods are focused to obtain different layers with promising features towards upscaling of cells in the direction of large-active-area perovskite modules. ${ }^{123-125}$
2.6.1. Large-area flexible devices. Di Giacomo et al. ${ }^{126}$ have breakthrough the normal studies, which concern about the laboratory-scale flexible perovskite cells, and fabricated the first flexible perovskite solar module. In that work, they succeeded to attain fully printed flexible cells via deposited perovskite and HTL layers with spin coating, in addition to obtaining the back electrode via evaporation ${ }^{127}$ or screen printed techniques. ${ }^{128}$ In addition, Hwang et al. actually explained the process to a 

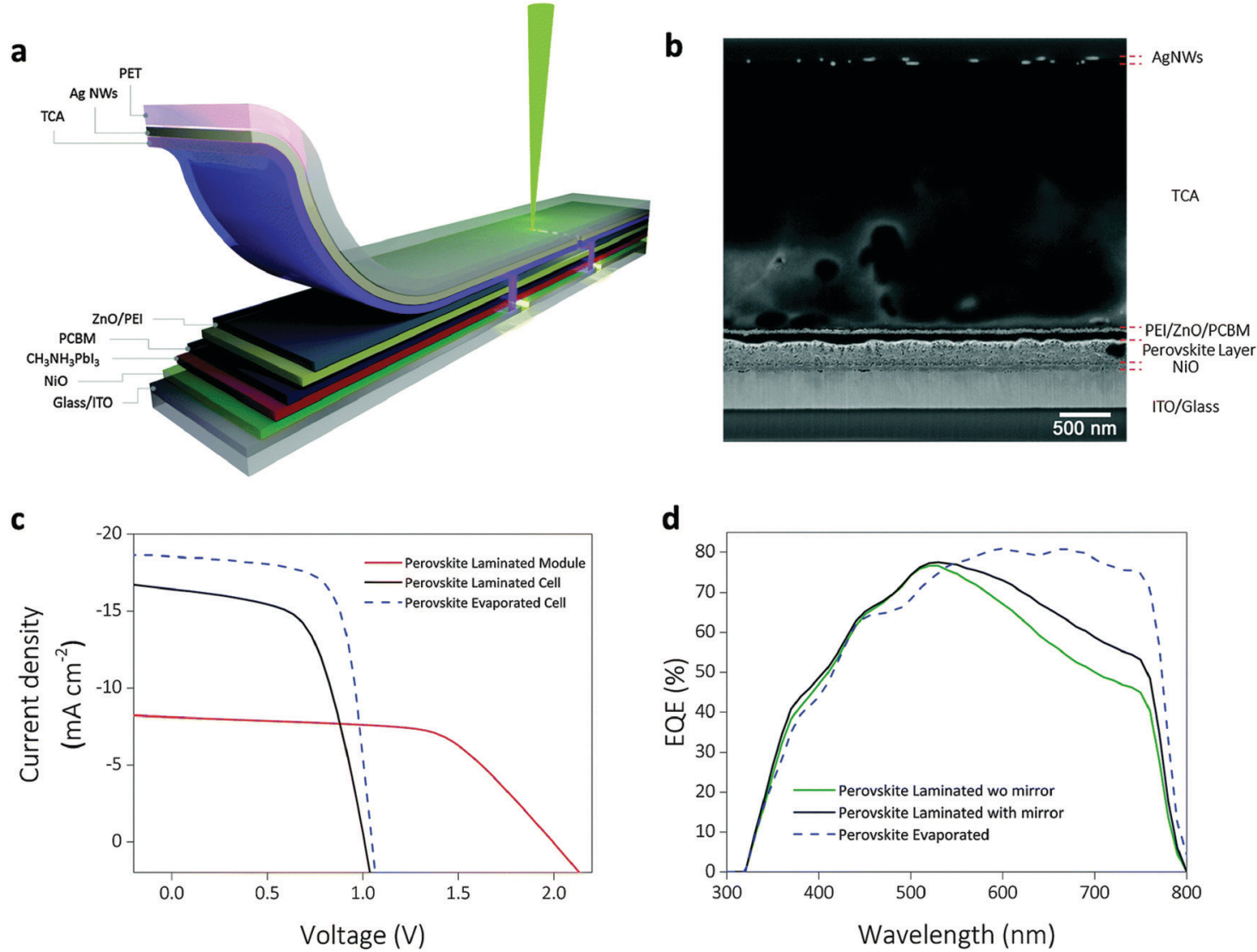

Fig. 8 (a) Device architecture of laminated perovskite solar cell/module. (b) Cross-section scanning electron microscopic image of a laminated perovskite solar device on a glass substrate. (c) $J-V$ characteristics of perovskite solar cells and modules with laminated top electrode. (d) EQE spectra of reference perovskite solar cell with $100 \mathrm{~nm}$ evaporated Ag top electrode (blue dashed line), laminated perovskite solar cells measured with reflecting mirror in the back (black line), and laminated OPV cell measured without reflecting mirror (green line). Reproduced with permission from ref. 103. Copyright (C) 2016 The Royal Society of Chemistry.

roll-to-roll printer, as shown in Fig. 10a. ${ }^{129}$ Additionally, 3D printing was used to prepare a simple air blade that targeted to form high-quality glassy $\mathrm{PbI}_{2}$ layer, which moved after that into a roll that acts as a small chamber to be then rehabilitated to cloudy $\mathrm{PbI}_{2}$. The layer was then easily transformed to a perovskite layer by slot die coating. Through that study, and by optimizing of roll-to-roll pathway, it shows an acceptable tendency to be used for the fabrication of large-scale modules in the future. ${ }^{129}$

Additionally, a photo of the printed perovskite module on a $10 \mathrm{~cm} \times 10 \mathrm{~cm}$ substrate is illustrated in Fig. 10b, showing that the module has 5 cells in series connection and each cell has $8 \mathrm{~cm}^{2}$ of active area. Furthermore, $I-V$ curves of the roll-to-roll printed perovskite module on ITO/PET and lab-scale printed perovskite solar cells on an ITO glass substrate are shown in Fig. 10 c. $^{129}$

2.6.2. Vapour-phase deposition. A number of methods like physical vapour deposition (PVD), sputter coating, chemical vapour deposition (CVD), and atomic layer deposition (ALD) as a representative for deposition pathways via vapour, which acts as a substitution to solution-based coating methods for perovskite films in order to accomplish large-scale modules.
Furthermore, Borchert et al. fabricated solar cells with an efficiency up to $14.2 \%$ through vapour-deposited layers, which paves the way in the direction of large-area stable perovskite modules. ${ }^{130-132}$

Furthermore, the schematic diagram in Fig. 11a illustrates the normal working distance in between the thermal sources and the rotating substrate in the evaporation system techniques that was found to be almost $20 \mathrm{~cm} \cdot{ }^{133}$ Regarding that distance as well as the radius of the system chamber, the thickness of the formed films will be affected and the center of the substrate will be much thicker compared to the rest of the substrate. In addition, the obtained film via deposition and after annealing can confirm through a photograph illustrated in Fig. 11b. Additionally, in order to attain both the surface roughness and surface coverage of the deposited film over an area of $5 \mu \mathrm{m} \times 5 \mu \mathrm{m}$, the atomic force microscopy (AFM) is considered as the best option to gain that important knowledge (Fig. 11c). ${ }^{133}$ The obtained data indicate that the surface roughness of the gained film is almost $R_{\mathrm{RMS}}=6.2 \mathrm{~nm}$, which confirms the formation of homogeneous, little light scattering and very smooth layer, with no pinholes films, as checked from all the image area. ${ }^{133-136}$ The gained value for that film, obtained via a 


\section{A. $\mathrm{CH}_{3} \mathrm{NH}_{3} \mathrm{PbI}_{3}$ compositional design to address fundamental material issues}
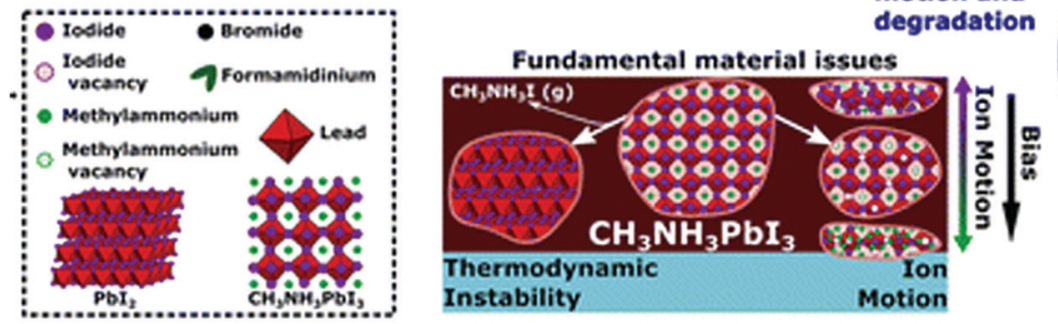

Partial substitution

of $\mathrm{CH}_{3} \mathrm{NH}_{3}{ }^{+}$and $\mathrm{I}$

to address ion

motion and

degradation

040000

0000000 .

, 00000004

0000004 .

0000000

0000

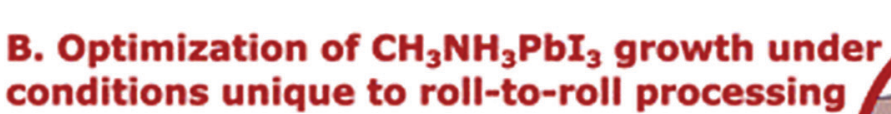
conditions unique to roll-to-roll processing

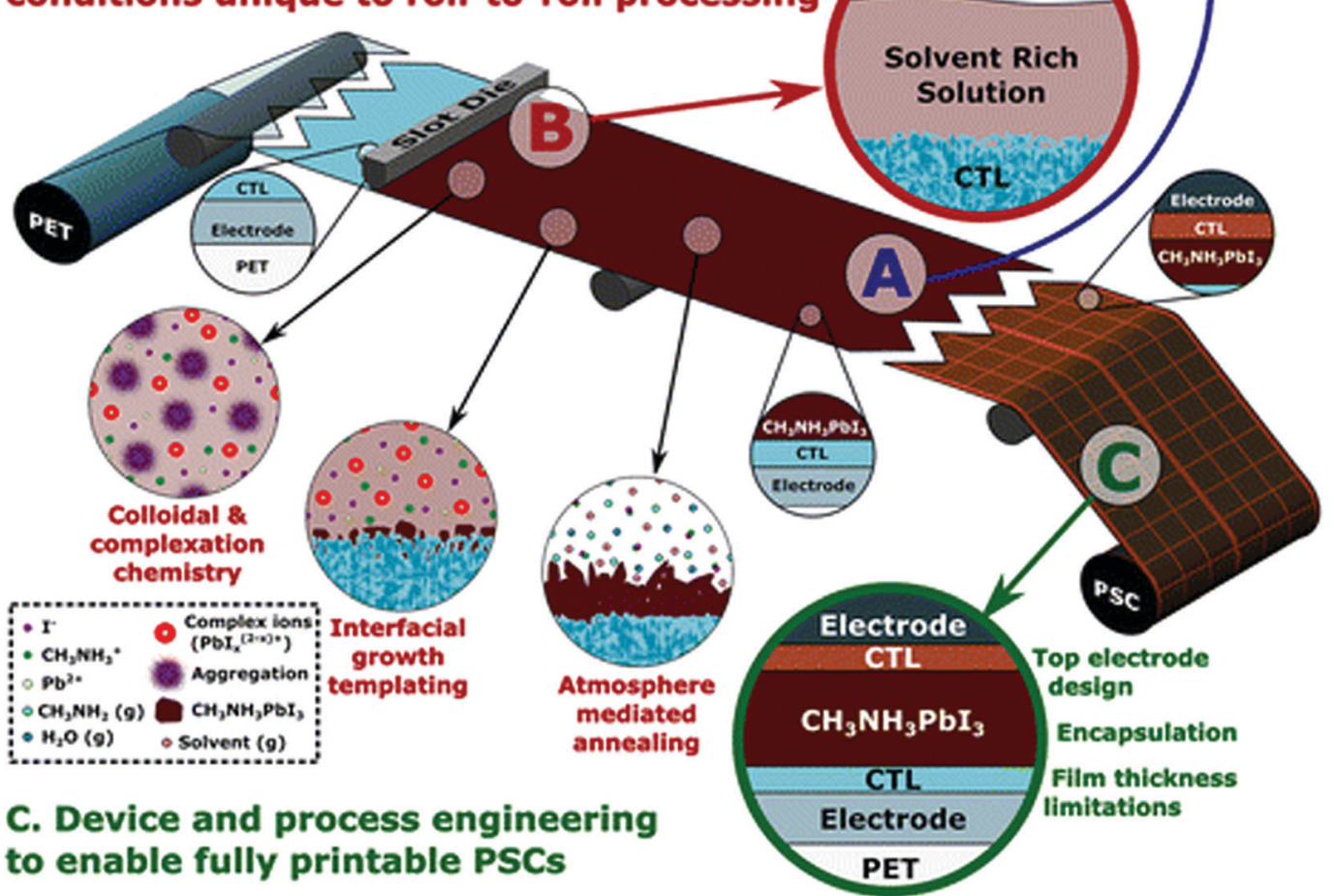

Fig. 9 Summary of research directions necessary to fuel PSC technological translation by slot-die R2R coating. (A) Material engineering can address intrinsic ion diffusivity and degradation of $\mathrm{CH}_{3} \mathrm{NH}_{3} \mathrm{Pbl}_{3}$, (B) optimization of perovskite growth under R2R conditions is necessary to reach performance requirements, and (C) device engineering is required to extend the device life and expand the material toolbox for the PSC design. Reproduced with permission from ref. 116. Copyright (C) 2016 American Chemical Society.

vapour deposition technique has a lower value of roughness compared to the value obtained for other materials like $\mathrm{FAPbI}_{3}$, with described roughness values ranging from $18 \mathrm{~nm}^{134}$ to above $100 \mathrm{~nm}^{135}$ Moreover, scanning electron microscopy (SEM) as well as scanning transmission electron microscopy (STEM) is considered as a faultless tool to detect the actual morphology and give acceptable study regarding the crystal quality of the formed films for the solar cell devices. A uniform film of $\mathrm{FAPbI}_{3}$, with no observable pinholes, can be exposed from the typical cross-sectional SEM image (Fig. 11d). ${ }^{136-138}$ However, STEM was found as an important tool for observing the crystal quality and interfaces of the fabricated devices via detecting the cross-sectional images of these device. The data gained from Fig. 11e confirms the crystallites of different orientations within the perovskite film, with some extending vertically in different positions of the film. Other issues can be confirmed via the STEM image, which is the high contrast between the $\mathrm{FAPbI}_{3}$ (bright) and the carbon-rich (dark) $\mathrm{C}_{60}$ and spiro-OMeTAD that surround it.

\section{State-of-the-art results for modules}

Compared to the state-of-the-art PCEs for spin-coated PSCs, which reached recently almost $25.2 \%{ }^{2}$ the PCEs of PSMs handled via scalable solution deposition procedures examined in the current review show less state-of-the-art records due to less optimization and control the engineering of those 


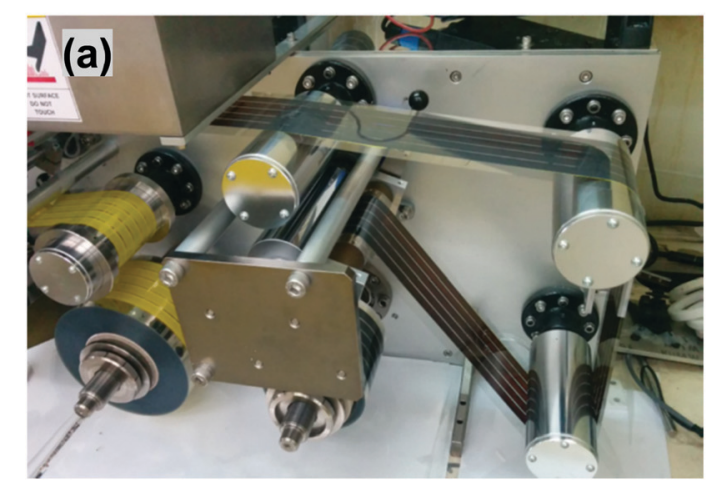

(b)

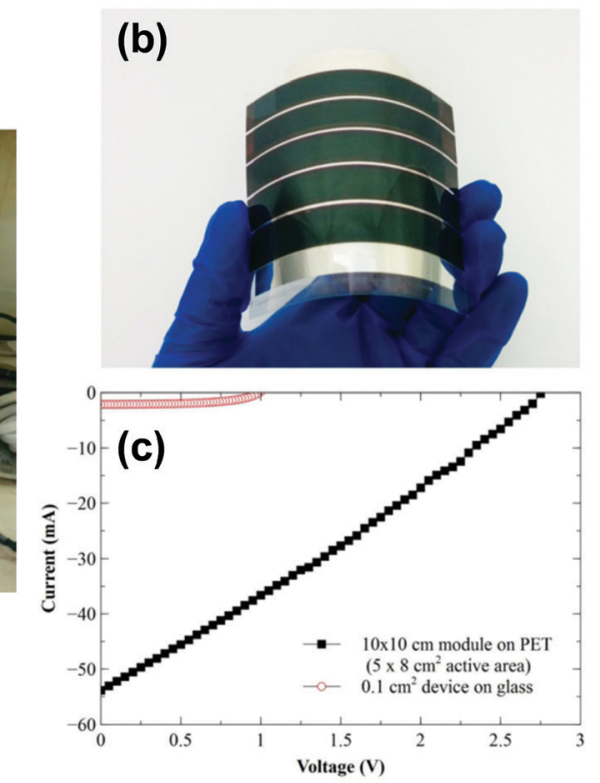

Fig. 10 Roll-to-roll production of flexible perovskite solar cell module. (a) Roll-to-roll converted perovskite film from the cloudy Pbl 2 layer. (b) A photo of the printed perovskite module on a $10 \mathrm{~cm} \times 10 \mathrm{~cm}$ substrate. The module has 5 cells in series connection and each cell has $8 \mathrm{~cm}{ }^{2}$ of active area. (c) $I-V$ curves of roll-to-roll printed perovskite module on ITO/PET and lab-scale-printed perovskite solar cells on ITO glass. Reproduced with permission from ref. 129. Copyright (C) 2015 WILEY-VCH.

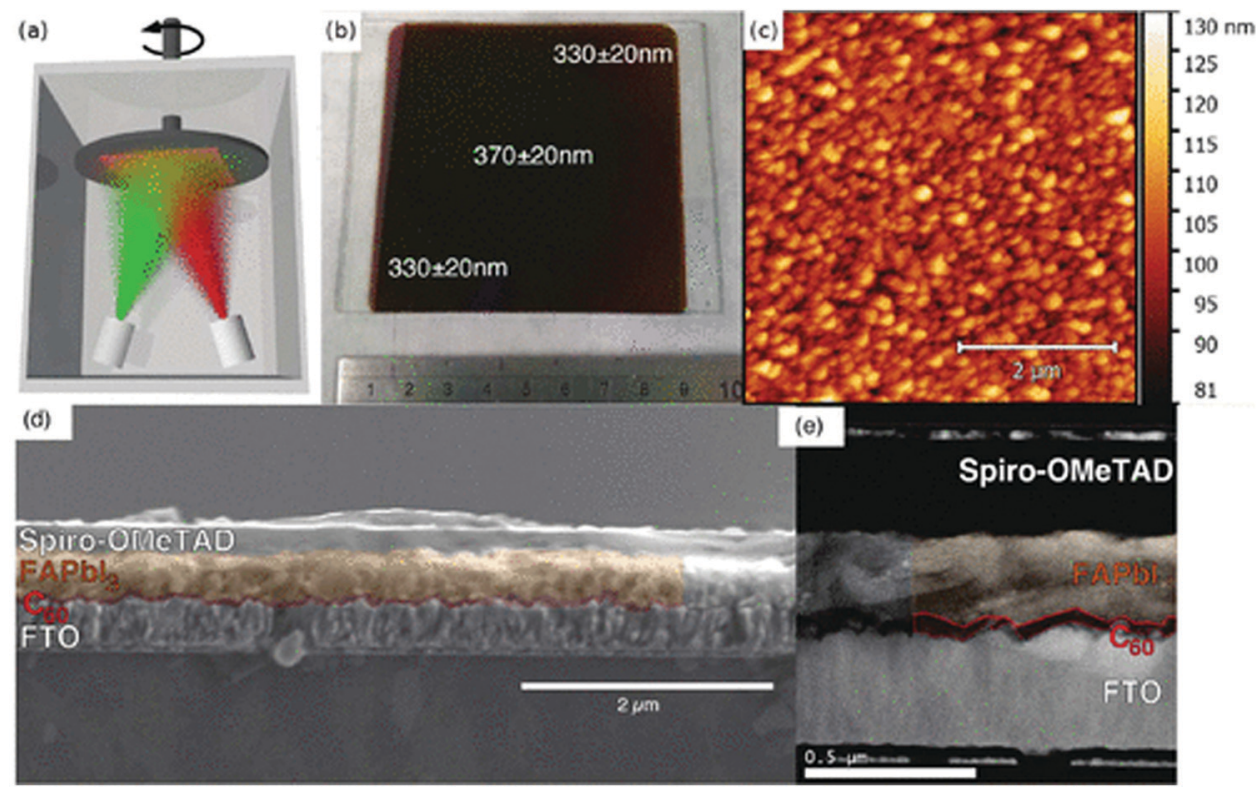

Fig. 11 (a) Schematic of the dual-source co-evaporation system used in this study. (b) Photograph of a $8 \mathrm{~cm} \times 8 \mathrm{~cm}$ thin film of FAPbl 3 deposited on a glass substrate. The image shows the substrate after thermal annealing at $170{ }^{\circ} \mathrm{C}$ for $1 \mathrm{~min}$. The results of thickness measurements at three positions are superimposed on the image, and a metal ruler with a centimetre scale is shown as a size reference. (c) Atomic force micrograph of a $5 \mu \mathrm{m} \times 5 \mu \mathrm{m}$ region of the sample. The surface was found to be very smooth with a root-mean-square roughness $R_{\mathrm{RMS}}=6.2 \mathrm{~nm}$. (d) A scanning electron microscopic image and (e) a scanning transmission electron microscopic image of a full FAPbl 3 solar cell. From the bottom, the layers are a glass substrate; a fluorine-doped tin oxide (FTO) layer, a thin $\mathrm{C}_{60}$ layer, a FAPbl 3 layer, a spiroOMeTAD layer, and the silver electrode. Reproduced with permission from ref. 133. Copyright (C) 2017 American Chemical Society.

techniques. In Table 1, the contemporary accomplishments for coating pathways, different parameters related to the fabricated modules including perovskite structure, $J-V$-characteristics, solar cell area, modules area and PCEs are summarized. Intended for numerous deliberated scalable deposition methods (blade coating, slot-die coating, inkjet printing, and spray coating), the first approach was reported 5 years ago. ${ }^{139}$ However, the researchers started to focus on the upscaling of perovskite solar cells toward attaining PSMs, the enhancement of scalable solution-based deposition pathways lateness a lot if it is 
Table 1 Several studies on perovskite solar modules (PSMs) employing the series interconnections with different cells and with total areas more than $10 \mathrm{~cm}^{2 a}$

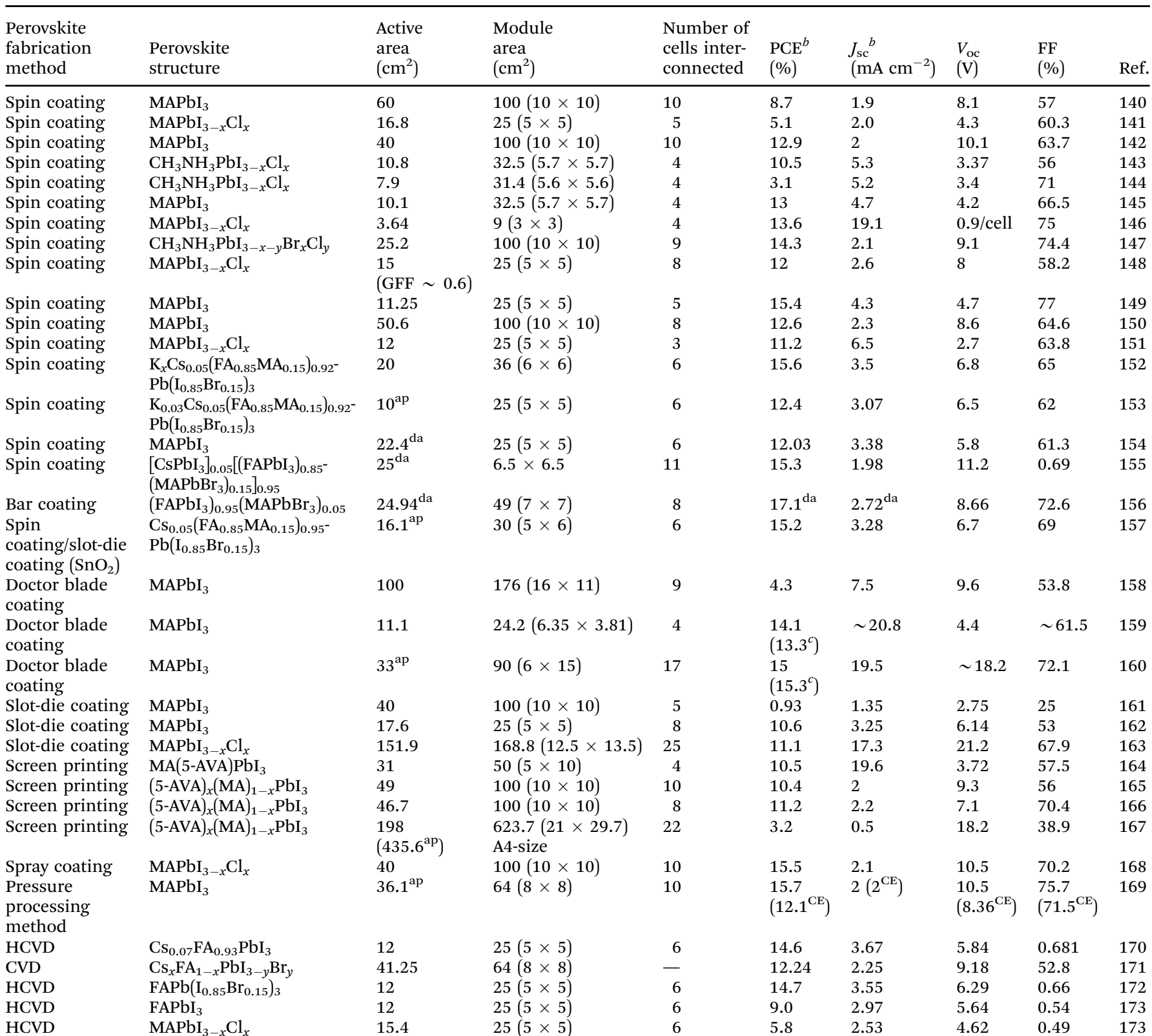

${ }^{a}$ The PCE and $J_{\mathrm{sc}}$ values are provided normalized by the active area unless otherwise stated: ap, aperture area; da, designated area (active area + dead area for interconnections). CE, certified efficiency; 5-AVA, 5-aminovaleric acid. ${ }^{b}$ Normalized by active area. ${ }^{c}$ Stabilized PCE.

compared with the values of PCEs for small-area spin coating PSCs method.

\section{Perovskite solar module stability and degradation characterization}

After obtaining the perovskite solar modules via different techniques and trying to improve the stability through understanding of the degradation mechanisms, it is not easy to confirm the stability and reliability of them toward the commercial attainment of perovskite photovoltaic (PV) technology. ${ }^{174-177}$ On the whole, contemporary explanations have shown the prominence of the interfaces within the device that can enhance the devices efficiency as well as stability via incorporating suitable charge-transport layers and electrode materials with appropriate compositions. Auxiliary grasp should be given to the degradation processes of perovskite modules, which have low stability issues in order to confirm the importance of the interfaces and how it can change by time. ${ }^{178}$

Different techniques are suitable for characterizing the stability of module scale with large-area perovskite materials 
similar to the laboratory-scale to detect the features of materials at the film and device levels, also to detect the degradation at the module that is more intricate compared to small cell, as well as the interconnection features in modules. ${ }^{179,180}$

\subsection{Cost, market potential and life cycle assessment of the modules}

Empowering the production of solar module systems with lowcost and long-term sustainability are the current target to be achieved in order to overcome the challenged that faced the upscaling of PSCs in the direction of PSMs. ${ }^{181}$ In the literature, many research studies go forward to confirm the positive effect of lowering the fabrication cost of the perovskite modules and to reach the long-term sustainability. ${ }^{182-184}$ Nevertheless, even though these different directions tried to control the cost of the fabrication process to attain the modules, through controlling weight, structure and encapsulation of the module, the stability factor is an obstacle to continue the progress of that kind of perovskite modules. ${ }^{182}$

Disablements to PSC energy grid incorporation enable the market contribution to be more probable through steady purification via these function markets. In consequence, this technology can offer superior admission toward scaling up large-area, flexible device fabrication that gain wide attention for the module market. For the research community, these current market authenticities best part fully printable PSCs and PSMs as a dynamic target intended for improvement.

Life cycle assessments are considered as an essential aspect, which concern on some of the cells and modules architectures (n-i-p structure), to confirm and detect sustainability as well as the environmental impact of PSCs and PSMs. ${ }^{185}$ It is imperative to consider the life cycle limited extent assessments that have been used in comparing PSCs with other traditional directions.

\section{Challenges facing upscaling perovskite photovoltaics}

Many challenges can exist while trying to upscale PSCs like the deposited materials as well as the processing techniques for fabrication, which cause depression towards large-scale positioning and may affect the device layers and the module interconnection. In fact, active area, stability as well as the cost of the proposed materials can be possible drawbacks facing the commercial upscaling of PSCs. The secrets behind the ideal device fabrication, including the amalgamations between architecture-materials to gain high performance and longterm stable devices, due to the changing in the material processing properties, still disappear that increase the existence of these challenges plainly. Besides, the active area can be affected by the series resistance of the electrodes, which resulted from the quality of configuration of the assembled layers via the coverage and uniformity, and decrease the net efficiency and stability of the invented laboratory-scale devices and modules. Moreover, the temperature, illumination and humidity may predispose the fabricated module efficiency and stability that suppose as a significant shortcoming of PSCs. By reducing both the cost and energy consumption of resource extraction including material synthesis and film processing for the different components in PSCs as well as PSMs, it will result in decreasing the cost and environmental impact of the final PV modules.

\section{Outlook and future perspectives}

Many research directions are focused on large-scale perovskite modules to improve the fabrication techniques. However, these studies tried to optimize the ideal device architecture, but there are some drawbacks challenging the upscaling of perovskite solar cells such as the used materials, module interconnection as well as the processing challenges, including composition of perovskites. These compositions become more complex to control while conveying into the production scale and hence affect the cost of assembly, high efficiency and/or the stability of the modules. Take the price as well as environmental influence of the assembled PV modules down that will necessitate additional decreases in the cost and energy consumption of resource extraction, material preparation as well as film processing for several PSCs constituents. ${ }^{186-188}$ In addition, there are several characteristics that may enhance both the fabrication and the efficiency of the assembled modules as follows:

(1) The existence of FTO substrates with high conductivity is essential to overcome the possible series resistance that may be found while assembling the solar modules. In addition to that, we should keep the optical transmittance option in order to gain all the needed features for the fabricated modules.

(2) To optimize the assembled perovskite solar module design, several parameters should be taken into account such as the deposited layers as well as the active area of the module that should be enlarged, while at the same time, the mismatch loss and internal resistance should be reduced.

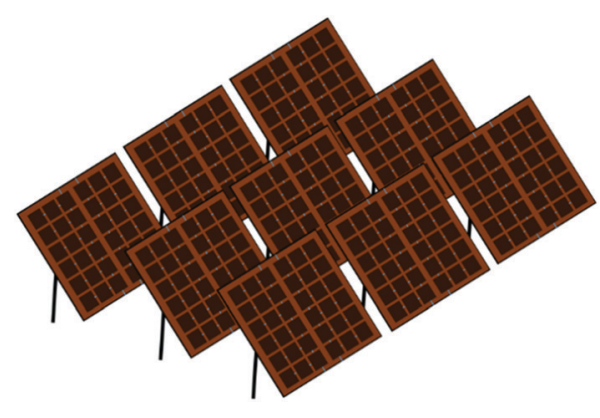

(3) The improvement of the auto production line is an essential step in the upscaling process, supporting unremitting and manageable fabrication process of the module. Additionally, in order to facilitate the fabrication of perovskite modules in terawatt large-scale with reasonable cost forming and life cycle assessments, the model architecture for the fabricated devices with scalable ingredients will be recognized. ${ }^{188-190}$ To conclude, because of the extraordinary advancement for 
proficiency as well as long-term stability of PSCs, it is progressively necessary to think through the performance functions in the framework of scalability. It is yet precocious to understand the challenges of scaling up PSCs with reverence to the countless stacks and efficacious arrangements for module interconnection. Nonetheless, the quick progress on the way to scaling up at an appropriate performance side by side (efficiency and stability) together with the low industrialised charge competence has been previously involved in the worldwide industrial interest. The challenges for PSC scaling give a clear figure toward work requirements, which is versed by industries to ensure attaining high-efficiency and stability scalable modules.

\section{Conflicts of interest}

The author declare no conflict of interest.

\section{Acknowledgements}

AES is currently on leave from CMRDI. In addition, the author appreciates the assistance of BCMaterials in Spain to follow up this study through its facilities. Furthermore, AES thanks the National Research grants from MINECO "Juan de la Cierva" [FJCI-2018-037717].

\section{References}

1 A. Kojima, K. Teshima, Y. Shirai and T. Miyasaka, J. Am. Chem. Soc., 2009, 131, 6050-6051.

2 National Revewable Energy Laboratory (NREL), Best Research-Cell Efficiencies, https:/www.nrel.gov/pv/cellefficiency.html, accessed: March 2020.

3 A. E. Shalan, T. Oshikiri, S. Narra, M. M. Elshanawany, K. Ueno, H.-P. Wu, K. Nakamura, X. Shi, E. W.-G. Diau and H. Misawa, ACS Appl. Mater. Interfaces, 2016, 8, 33592-33600. 4 A. M. Elseman, A. E. Shalan, S. Sajid, M. M. Rashad, A. M. Hassan and M. Li, ACS Appl. Mater. Interfaces, 2018, 10, 11699-11707.

5 C. S. Ponseca Jr., T. J. Savenije, M. Abdellah, K. Zheng, A. Yartsev, T. Pascher, T. Harlang, P. Chabera, T. Pullerits, A. Stepanov, J.-P. Wolf and V. Sundstrom, J. Am. Chem. Soc., 2014, 136, 5189.

6 K.-G. Lim, S. Ahn, Y.-H. Kim, Y. Qi and T.-W. Lee, Energy Environ. Sci., 2016, 9, 932.

7 Q. Dong, Y. Fang, Y. Shao, P. Mulligan, J. Qiu, L. Cao and J. Huang, Science, 2015, 347, 967.

8 D. Shi, V. Adinolfi, R. Comin, M. J. Yuan, E. Alarousu, A. Buin, Y. Chen, S. Hoogland, A. Rothenberger, K. Katsiev, Y. Losovyj, X. Zhang, P. A. Dowben, O. F. Mohammed, E. H. Sargent and O. M. Bakr, Science, 2015, 347, 519.

9 S. D. Stranks, G. E. Eperon, G. Grancini, C. Menelaou, M. J. P. Alcocer, T. Leijtens, L. M. Herz, A. Petrozza and H. J. Snaith, Science, 2013, 342, 341.
10 G. Xing, N. Mathews, S. Sun, S. S. Lim, Y. M. Lam, M. Gratzel, S. Mhaisalkar and T. C. Sum, Science, 2013, $342,344$.

11 V. D. Innocenzo, G. Grancini, M. J. P. Alcocer, A. R. S. Kandada, S. D. Stranks, M. M. Lee, G. Lanzani, H. J. Snaith and A. Petrozza, Nat. Commun., 2014, 5, 3586.

12 M. M. Voigt, F. Machui, L. Lucera, G. Spyropoulos, J. Cordero, P. Kubis, A. S. Ali, A. E. Shalan and C. J. Brabec, Photovoltaic Specialists Conference (PVSC), 2013 IEEE 39th, pp. 3092-3097.

13 A. N. El-Shazly, A. E. Shalan, M. M. Rashad, E. A. Abdel-Aal, I. A. Ibrahim and M. F. El-Shahat, $R S C A d v$., 2018, 8, 24059-24067.

14 A. E. Shalan and M. M. Rashad, Appl. Surf. Sci., 2013, 283, 975-981.

15 M. M. Rashad, A. E. Shalan, M. Lira-Cantu and M. S. A. Abdel-Mottaleb, J. Ind. Eng. Chem., 2013, 19, 2052-2059.

16 A. E. Shalan, M. Rasly, I. Osama, M. M. Rashad and I. A. Ibrahim, Ceram. Int., 2014, 40, 11619-11626.

17 A. E. Shalan, A. M. Elseman, M. Rasly, M. M. Moharam, M. Lira-Cantu and M. M. Rashad, RSC Adv., 2015, 5, 103095-103104.

18 A. E. Shalan, M. M. Rashad, Y. Yu, M. Lira-Cantú and M. S. A. Abdel-Mottaleb, Electrochim. Acta, 2013, 89, 469-478.

19 M. M. Rashad and A. E. Shalan, Appl. Phys. A: Mater. Sci. Process., 2014, 116, 781-788.

20 E. M. Elsayed, A. E. Shalan and M. M. Rashad, J. Mater. Sci.: Mater. Electron., 2014, 25, 3412-3419.

21 A. E. Shalan, S. Narra, T. Oshikiri, K. Ueno, X. Shi, H.-P. Wu, M. M. Elshanawany, E. W.-G. Diau and H. Misawa, Sustainable Energy Fuels, 2017, 1, 1533-1540.

22 A. E. Shalan, T. Oshikiri, H. Sawayanagi, K. Nakamura, K. Ueno, Q. Sun, H.-P. Wu, E. W.-G. Diau and H. Misawa, Nanoscale, 2017, 9, 1229-1236.

23 A. M. Elseman, S. Sajid, A. E. Shalan, S. A. Mohamed and M. M. Rashad, Appl. Phys. A: Mater. Sci. Process., 2019, 125, 476.

24 A. E. Shalan, S. Kazim and S. Ahmad, ChemSusChem, 2019, 12, 4116-4139.

25 A. M. Elseman, A. E. Shalan, M. M. Rashad and A. M. Hassan, Mater. Sci. Semicond. Process., 2017, 66, 176-185.

26 A. E. Shalan, A. N. El-Shazly, M. M. Rashad and N. K. Allam, Nanoscale Adv., 2019, 1, 2654-2662.

27 J.-H. Im, C.-R. Lee, J.-W. Lee, S.-W. Park and N.-G. Park, Nanoscale, 2011, 3, 4088.

28 Z. Li, T. R. Klein, D. H. Kim, M. J. Yang, J. J. Berry, M. F. A. M. van Hest and K. Zhu, Nat. Rev. Mater., 2018, 3, 18017.

29 J. Seo, S. Park, Y. C. Kim, N. J. Jeon, J. H. Noh, S. C. Yoon and S. I. Sang, Energy Environ. Sci., 2014, 7, 2642.

30 J. H. Heo, H. J. Han, D. Kim, T. K. Ahn and S. H. Im, Energy Environ. Sci., 2015, 8, 1602.

31 A. B. Djurisic, F. Z. Liu, H. W. Tam, M. K. Wong, A. Ng, C. Surya, W. Chen and Z. B. He, Prog. Quantum Electron., 2017, 53, 1.

32 P. Cheng and X. Zhan, Chem. Soc. Rev., 2016, 45, 2544. 
33 F. Wang, Y. Cao, C. Chen, Q. Chen, X. Wu, X. Li, T. Qin and W. Huang, Adv. Funct. Mater., 2018, 28, 1803753.

34 T. Bu, X. Liu, Y. Zhou, J. Yi, X. Huang, L. Luo, J. Xiao, Z. Ku, Y. Peng, F. Huang, Y.-B. Cheng and J. Zhong, Energy Environ. Sci., 2017, 10, 2509-2515.

35 Y. Deng, X. Zheng, Y. Bai, Q. Wang, J. Zhao and J. Huang, Nat. Energy, 2018, 3, 560-566.

36 T. Bu, J. Li, F. Zheng, W. Chen, X. Wen, Z. Ku, Y. Peng, J. Zhong, Y.-B. Cheng and F. Huang, Nat. Commun., 2018, 9, 4609.

37 K. Li, J. Xiao, X. Yu, T. Bu, T. Li, X. Deng, S. Liu, J. Wang, Z. Ku, J. Zhong, F. Huang, Z. Zhong, Y. Peng, W. Li and Y. Cheng, ACS Appl. Energy Mater., 2018, 1, 3565-3570.

38 F. Matteocci, S. Casaluci, S. Razza, A. Guidobaldi, T. M. Brown, A. Reale and A. Di Carlo, J. Power Sources, 2014, 246, 361.

39 F. Giordano, A. Guidobaldi, E. Petrolati, L. Vesce, R. Riccitelli, A. Reale, T. M. Brown and A. Di Carlo, Prog. Photovoltaics, 2013, 21, 1653.

40 H. Hoppe, M. Seeland and B. Muhsin, Sol. Energy Mater. Sol. Cells, 2012, 97, 119.

41 Y. Galagan, E. W. C. Coenen, W. Verhees and R. Andriessen, J. Mater. Chem. A, 2016, 4, 5700.

42 S. Razza, S. Castro-Hermosa, A. Di Carlo and T. M. Brown, APL Mater., 2016, 4, 091508.

43 N. J. Jeon, J. H. Noh, Y. C. Kim, W. S. Yang, S. Ryu and S. I. Seok, Nat. Mater., 2014, 13, 897-903.

44 K. Wojciechowski, S. D. Stranks, A. Abate, G. Sadoughi, A. Sadhanala, N. Kopidakis, G. Rumbles, C.-Z. Li, R. H. Friend, A. K.-Y. Jen and H. J. Snaith, ACS Nano, 2014, 8, 12701-12709.

45 Y. Hou, C. O. R. Quiroz, S. Scheiner, W. Chen, T. Stubhan, A. Hirsch, M. Halik and C. J. Brabec, Adv. Energy Mater., 2015, 5, 1501056.

46 W. Ke, D. Zhao, C. Xiao, C. Wang, A. J. Cimaroli, C. R. Grice, M. Yang, Z. Li, C.-S. Jiang, M. Al-Jassim, K. Zhu, M. G. Kanatzidis, G. Fang and Y. Yan, J. Mater. Chem. A, 2016, 4, 14276-14283.

47 Z. Ku, Y. Rong, M. Xu, T. Liu and H. Han, Sci. Rep., 2013, 3, 3132 .

48 V. Zardetto, B. L. Williams, A. Perrotta, F. Di Giacomo, M. A. Verheijen, R. Andriessen, W. M. M. Kessels and M. Creatore, Sustainable Energy Fuels, 2017, 1, 30.

49 S.-J. Moon, J.-H. Yum, L. Lofgren, A. Walter, L. Sansonnens, M. Benkhaira, S. Nicolay, J. Bailat and C. Ballif, IEEE J. Photovolt., 2015, 5, 1087-1092.

50 M. A. Green, K. Emery, Y. Hishikawa, W. Warta and E. D. Dunlop, Prog. Photovoltaics, 2012, 20, 12-20.

51 L. K. Ono, N.-G. Park, K. Zhu, W. Huang and Y. Qi, ACS Energy Lett., 2017, 2, 1749-1751.

52 Z. Song, A. Abate, S. C. Watthage, G. K. Liyanage, A. B. Phillips, U. Steiner, M. Graetzel and M. J. Heben, Adv. Energy Mater., 2016, 6, 1600846.

53 V. M. Fthenakis and P. D. Moskowitz, Prog. Photovoltaics, 2000, 8, 27-38.

54 A. Babayigit, A. Ethirajan, M. Muller and B. Conings, Nat. Mater., 2016, 15, 247-251.
55 Z. Song, C. L. McElvany, A. B. Phillips, I. Celik, P. W. Krantz, S. C. Watthage, G. K. Liyanage, D. Apul and M. J. Heben, Energy Environ. Sci., 2017, 10, 1297.

56 J. Seo, S. Park, Y. C. Kim, N. J. Jeon, J. H. Noh, S. C. Yoon and S. I. Seok, Energy Environ. Sci., 2014, 7, 2642-2646.

57 T. Bu, X. Liu, R. Chen, Z. Liu, K. Li, W. Li, Y. Peng, Z. Ku, F. Huang, Y.-B. Cheng and J. Zhong, J. Mater. Chem. A, 2018, 6, 6319-6326.

58 W. Chen, Y. Wu, Y. Yue, J. Liu, W. Zhang, X. Yang, H. Chen, E. Bi, I. Ashraful, M. Gratzel and L. Han, Science, 2015, 350, 944.

59 M. Yang, Y. Zhou, Y. Zeng, C.-S. Jiang, N. P. Padture and K. Zhu, Adv. Mater., 2015, 27, 6363.

60 W. Qiu, T. Merckx, M. Jaysankar, C. Masse de la Huerta, L. Rakocevic, W. Zhang, U. W. Paetzold, R. Gehlhaar, L. Froyen, J. Poortmans, D. Cheyns, H. J. Snaith and P. Heremans, Energy Environ. Sci., 2016, 9, 484.

61 X. Li, D. Bi, C. Yi, J.-D. Décoppet, J. Luo, S. M. Zakeeruddin, A. Hagfeldt and M. Grätzel, Science, 2016, 353, 58-62.

62 A. Agresti, S. Pescetelli, A. L. Palma, A. E. Del Rio Castillo, D. Konios, G. Kakavelakis, S. Razza, L. Cina, E. Kymakis, F. Bonaccorso and A. Di Carlo, ACS Energy Lett., 2017, 2, 279-287.

63 Z. Yang, C.-C. Chueh, F. Zuo, J. H. Kim, P.-W. Liang and A. K.-Y. Jen, Adv. Energy Mater., 2015, 5, 1500328.

64 A. T. Mallajosyula, K. Fernando, S. Bhatt, A. Singh, B. W. Alphenaar, J.-C. Blancon, W. Nie, G. Gupta and A. D. Mohite, Appl. Mater. Today, 2016, 3, 96.

65 S. Tong, H. Wu, C. Zhang, S. Li, C. Wang, J. Shen, S. Xiao, J. He, J. Yang, J. Sun and Y. Gao, Org. Electron., 2017, 49, 347-354.

66 Y. Deng, Q. Wang, Y. Yuan and J. Huang, Mater. Horiz., 2015, 2, 578-583.

67 S.-G. Li, K.-J. Jiang, M.-J. Su, X.-P. Cui, J.-H. Huang, Q.-Q. Zhang, X.-Q. Zhou, L.-M. Yang and Y.-L. Song, J. Mater. Chem. A, 2015, 3, 9092-9097.

68 D. Vak, K. Hwang, A. Faulks, Y. S. Jung, N. Clark, D. Y. Kim, G. J. Wilson and S. E. Watkins, Adv. Energy Mater., 2015, 5,1 .

69 F. Ye, H. Chen, F. Xie, W. Tang, M. Yin, J. He, E. Bi, Y. Wang, X. Yang and L. Han, Energy Environ. Sci., 2016, 9, 2295-2301.

70 W. C. Chang, D. H. Lan, K. M. Lee, X. F. Wang and C. L. Liu, ChemSusChem, 2017, 10, 1405-1412.

71 S. Das, B. Yang, G. Gu, P. C. Joshi, I. N. Ivanov, C. M. Rouleau, T. Aytug, D. B. Geohegan and K. Xiao, ACS Photonics, 2015, 2, 680-686.

72 S. Razza, S. Castro-Hermosa, A. Di Carlo and T. M. Brown, APL Mater., 2016, 4, 091508.

73 K. Hwang, Y. S. Jung, Y. J. Heo, F. H. Scholes, S. E. Watkins, J. Subbiah, D. J. Jones, D. Y. Kim and D. Vak, Adv. Mater., 2015, 27, 1241-1247.

74 Z. Yang, C. C. Chueh, F. Zuo, J. H. Kim, P. W. Liang and A. K. Y. Jen, Adv. Energy Mater., 2015, 5, 1500328.

75 Y. Deng, E. Peng, Y. Shao, Z. Xiao, Q. Dong and J. Huang, Energy Environ. Sci., 2015, 8, 1544-1550. 
76 I. M. Hossain, D. Hudry, F. Mathies, T. Abzieher, S. Moghadamzadeh, D. Rueda-Delgado, F. Schackmar, M. Bruns, R. Andriessen, T. Aernouts, F. D. Giacomo, U. Lemmer, B. S. Richards, U. W. Paetzold and A. Hadipour, ACS Appl. Energy Mater., 2019, 2, 47-58.

77 E. H. Anaraki, A. Kermanpur, L. Steier, K. Domanski, T. Matsui, W. Tress, M. Saliba, A. Abate, M. Gratzel, A. Hagfeldt and J. Correa-Baena, Energy Environ. Sci., 2016, 9, 3128-3134.

78 A. Baltakesmez, M. Biber and S. Tuzemen, J. Radiat. Res. Appl. Sci., 2018, 11, 124-129.

79 J. You, L. Meng, T. Song, T. Guo, Y. M. Yang, W. Chang, Z. Hong, H. Chen, H. Zhou, Q. Chen, Y. Liu, N. De Marco and Y. Yang, Nat. Nanotechnol., 2016, 11, 75-81.

80 Z. Liang, S. Zhang, X. Xu, N. Wang, J. Wang, X. Wang, Z. Bi, G. Xu, N. Yuan and J. Ding, RSC Adv., 2015, 5, 60562-60569.

81 J. H. Heo, M. H. Lee, M. H. Jang and S. H. Im, J. Mater. Chem. A, 2016, 4, 17636-17642.

82 D. K. Mohamad, J. Griffin, C. Bracher, A. T. Barrows and D. G. Lidzey, Adv. Energy Mater., 2016, 6, 1600994.

83 A. T. Barrows, A. J. Pearson, C. K. Kwak, A. D. F. Dunbar, A. R. Buckley and D. G. Lidzey, Energy Environ. Sci., 2014, 7, 2944.

84 M. Ramesh, K. M. Boopathi, T. Y. Huang, Y. C. Huang, C. S. Tsao and C. W. Chu, ACS Appl. Mater. Interfaces, 2015, 7, 2359.

85 S. Das, B. Yang, G. Gu, P. C. Joshi, I. N. Ivanov, C. M. Rouleau, T. Aytug, D. B. Geohegan and K. Xiao, ACS Photonics, 2015, 2, 680.

86 X. Xia, W. Wu, H. Li, B. Zheng, Y. Xue, J. Xu, D. Zhang, C. Gao and X. Liu, RSC Adv., 2016, 6, 14792.

87 H. Huang, J. Shi, L. Zhu, D. Li, Y. Luo and Q. Meng, Nano Energy, 2016, 27, 352.

88 J. H. Heo, M. H. Lee, M. H. Jang and S. H. Im, J. Mater. Chem. A, 2016, 4, 17636.

89 J. E. Bishop, T. J. Routledge and D. G. Lidzey, J. Phys. Chem. Lett., 2018, 9, 1977.

90 S. Razza, S. Castro-Hermosa, A. Di Carlo and T. M. Brown, APL Mater., 2016, 4, 091508.

91 I. A. Howard, T. Abzieher, I. M. Hossain, H. Eggers, F. Schackmar, S. Ternes, B. S. Richards, U. Lemmer and U. W. Paetzold, Adv. Mater., 2019, 31, 1806702.

92 Y. Rong, Z. Ku, A. Mei, T. Liu, M. Xu, S. Ko, X. Li and H. Han, J. Phys. Chem. Lett., 2014, 5, 2160.

93 L. Zhang, T. Liu, L. Liu, M. Hu, Y. Yang, A. Mei and H. Han, J. Mater. Chem. A, 2015, 3, 9165.

94 Z. Ku, Y. Rong, M. Xu, T. Liu and H. Han, Sci. Rep., 2013, 3, 3132 .

95 A. Mei, X. Li, L. Liu, Z. Ku, T. Liu, Y. Rong, M. Xu, M. Hu, J. Chen, Y. Yang, M. Gratzel and H. Han, Science, 2014, 345, 295.

96 Z. L. Ku, Y. G. Rong, M. Xu, T. F. Liu and H. W. Han, Sci. Rep., 2013, 3, 3132.

97 A. Y. Mei, X. Li, L. F. Liu, Z. L. Ku, T. F. Liu, Y. G. Rong, M. Xu, M. Hu, J. Z. Chen, Y. Yang, M. Gratzel and H. W. Han, Science, 2014, 345, 295.
98 Y. Hu, S. Si, A. Mei, Y. Rong, H. Liu, X. Li and H. Han, Sol. $R R L, 2017,1,1600019$.

99 A. Kay and M. Grätzel, Sol. Energy Mater. Sol. Cells, 1996, 44, 99.

100 S. G. Hashmi, D. Martineau, X. Li, M. Ozkan, A. Tiihonen, M. I. Dar, T. Sarikka, S. M. Zakeeruddin, J. Paltakari and P. Lund, Adv. Mater. Technol., 2016, 2, 1600183.

101 S. Nakano, T. Matsuoka, S. Kiyama, H. Kawata, N. Nakamura, Y. Nakashima, S. Tsuda, H. Nishiwaki, M. Ohnishi and I. Nagaoka, Jpn. J. Appl. Phys., 1986, 25, 1936.

102 S. Razza, F. Di Giacomo, F. Matteocci, L. Cina, A. L. Palma, S. Casaluci, P. Cameron, A. D'Epifanio, S. Licoccia, A. Reale, T. M. Brown and A. Di Carlo, J. Power Sources, 2015, 277, 286.

103 G. D. Spyropoulos, C. O. R. Quiroz, M. Salvador, Y. Hou, N. Gasparini, P. Schweizer, J. Adams, P. Kubis, N. Li, E. Spiecker, T. Ameri, H.-J. Egelhaaf and C. J. Brabec, Energy Environ. Sci., 2016, 9, 2302-2313.

104 C. O. Ramírez Quiroz, I. Levchuk, C. Bronnbauer, M. Salvador, K. Forberich, T. Heumüller, Y. Hou, P. Schweizer, E. Spiecker and C. J. Brabec, J. Mater. Chem. A, 2015, 3, 24071-24081.

105 J. Xiong, B. Yang, R. Wu, C. Cao, Y. Huang, C. Liu, Z. Hu, H. Huang, Y. Gao and J. Yang, Org. Electron., 2015, 24, 106-112.

106 Y. Shao, Z. Xiao, C. Bi, Y. Yuan and J. Huang, Nat. Commun., 2014, 5.

107 Q. Lin, A. Armin, R. C. R. Nagiri, P. L. Burn and P. Meredith, Nat. Photonics, 2015, 9, 106-112.

108 R. Sondergaard, M. Hosel, D. Angmo, T. T. Larsen-Olsen and F. C. Krebs, Mater. Today, 2012, 15, 36.

109 B. Susrutha, L. Giribabu and S. P. Singh, Chem. Commun., 2015, 51, 14696.

110 S. A. Gevorgyan, M. V. Madsen, H. F. Dam, M. Jorgensen, C. J. Fell, K. F. Anderson, B. C. Duck, A. Mescheloff, E. A. Katz, A. Elschner, R. Roesch, H. Hoppe, M. Hermenau, M. Riede and F. C. Krebs, Sol. Energy Mater. Sol. Cells, 2013, 116, 187.

111 F. C. Krebs, T. Tromholt and M. Jorgensen, Nanoscale, 2010, 2, 873.

112 R. Rosch, F. C. Krebs, D. M. Tanenbaum and H. Hoppe, Sol. Energy Mater. Sol. Cells, 2012, 97, 176.

113 T. M. Brown, F. De Rossi, F. Di Giacomo, G. Mincuzzi, V. Zardetto, A. Reale and A. Di Carlo, J. Mater. Chem. A, 2014, 2, 10788.

114 W. S. Yang, J. H. Noh, N. J. Jeon, Y. C. Kim, S. Ryu, J. Seo and S. I. Seok, Science, 2015, 348, 1234-1237.

115 Y.-Y. Zhang, S. Chen, P. Xu, H. Xiang, X.-G. Gong, A. Walsh and S. Wei, Chin. Phys. Lett., 2018, 35, 036104.

116 S. T. Williams, A. Rajagopal, C.-C. Chueh and A. K.-Y. Jen, J. Phys. Chem. Lett., 2016, 7, 811-819.

117 S. T. Williams, F. Zuo, C.-C. Chueh, C.-Y. Liao, P.-W. Liang and A. K.-Y. Jen, ACS Nano, 2014, 8, 10640-10654.

118 Y. Li, X. Wang, S. Wu, H. Ci, H. Xu, X. Li, H. Sun, Z. Zhang, A. Cao, X. Guo and Y. Li, J. Mater. Chem. A, 2015, 3, 18847-18851. 
119 Q. Chen, N. De Marco, Y. Yang, T.-B. Song, C.-C. Chen, H. Zhao, Z. Hong, H. Zhou and Y. Yang, Nano Today, 2015, 10, 355-396.

120 N. K. Noel, A. Abate, S. D. Stranks, E. S. Parrott, V. M. Burlakov, A. Goriely and H. J. Snaith, ACS Nano, 2014, 8, 9815-9821.

121 Q. Chen, H. Zhou, Z. Hong, S. Luo, H.-S. Duan, H.-H. Wang, Y. Liu, G. Li and Y. Yang, J. Am. Chem. Soc., 2014, 136, 622.

122 M. R. Leyden, Y. Jiang and Y. Qi, J. Mater. Chem. A, 2016, 4, 13125 .

123 J. Troughton, C. Charbonneau, M. J. Carnie, M. L. Davies, D. A. Worsley and T. M. Watson, J. Mater. Chem. A, 2015, 3, 9123.

124 J. Troughton, M. J. Carnie, M. L. Davies, C. Charbonneau, E. Jewell, D. A. Worsley and T. M. Watson, J. Mater. Chem. A, 2016, 4, 3471.

125 S. Das, G. Gu, P. C. Joshi, B. Yang, T. Aytug, C. M. Rouleau, D. B. Geohegan and K. Xiao, J. Mater. Chem. A, 2016, 4, 9685.

126 F. Di Giacomo, V. Zardetto, A. D. Epifanio, S. Pescetelli, F. Matteocci, S. Razza, A. Di Carlo, S. Licoccia, W. M. M. Kessels, M. Creatore and T. M. Brown, Adv. Energy Mater., 2015, 5, 1401808.

127 K. Shin, J. Park and C. Lee, Thin Solid Films, 2016, 598, 95.

128 T. M. Schmidt, T. T. Larsen-Olsen, J. E. Carle, D. Angmo and F. C. Krebs, Adv. Energy Mater., 2015, 5, 1500569.

129 K. Hwang, Y.-S. Jung, Y.-J. Heo, F. H. Scholes, S. E. Watkins, J. Subbiah, D. J. Jones, D.-Y. Kim and D. Vak, Adv. Mater., 2015, 27, 1241-1247.

130 J. Troughton, C. Charbonneau, M. J. Carnie, M. L. Davies, D. A. Worsley and T. M. Watson, J. Mater. Chem. A, 2015, 3, 9123.

131 J. Troughton, M. J. Carnie, M. L. Davies, C. Charbonneau, E. Jewell, D. A. Worsley and T. M. Watson, J. Mater. Chem. A, 2016, 4, 3471.

132 S. Das, G. Gu, P. C. Joshi, B. Yang, T. Aytug, C. M. Rouleau, D. B. Geohegan and K. Xiao, J. Mater. Chem. A, 2016, 4, 9685 .

133 J. Borchert, R. L. Milot, J. B. Patel, C. L. Davies, A. D. Wright, L. M. Maestro, H. J. Snaith, L. M. Herz and M. B. Johnston, ACS Energy Lett., 2017, 2, 2799-2804.

134 Y. Yu, C. Wang, C. R. Grice, N. Shrestha, J. Chen, D. Zhao, W. Liao, A. J. Cimaroli, P. J. Roland, R. J. Ellingson and Y. Yan, ChemSusChem, 2016, 9, 3288-3297.

135 Z. Xie, S. Sun, Y. Yan, L. Zhang, R. Hou, F. Tian and G. G. Qin, J. Phys.: Condens. Matter, 2017, 29, 245702.

136 T. W. Crothers, R. L. Milot, J. B. Patel, E. S. Parrott, J. Schlipf, P. Muller-Buschbaum, M. B. Johnston and L. M. Herz, Nano Lett., 2017, 17, 5782-5789.

137 M. B. Johnston and L. M. Herz, Acc. Chem. Res., 2016, 49, 146-154.

138 M. Sessolo, C. Momblona, L. Gil-Escrig and H. J. Bolink, MRS Bull., 2015, 40, 660-666.

139 M. H. Zori and A. Soleimani-Gorgani, J. Eur. Ceram. Soc., 2012, 32, 4271.
140 J. Seo, S. Park, Y. Chan Kim, N. J. Jeon, J. H. Noh, S. C. Yoon and S. I. Seok, Energy Environ. Sci., 2014, 7, 2642-2646.

141 F. Matteocci, S. Razza, F. Di Giacomo, S. Casaluci, G. Mincuzzi, T. M. Brown, A. D’Epifanio, S. Licoccia and A. Di Carlo, Phys. Chem. Chem. Phys., 2014, 16, 3918-3923.

142 J. H. Heo, H. J. Han, D. Kim, T. K. Ahn and S. H. Im, Energy Environ. Sci., 2015, 8, 1602-1608.

143 A. Fakharuddin, F. Di Giacomo, A. L. Palma, F. Matteocci, I. Ahmed, S. Razza, A. D'Epifanio, S. Licoccia, J. Ismail, A. Di Carlo, T. M. Brown and R. Jose, ACS Nano, 2015, 9, 8420-8429.

144 F. Di Giacomo, V. Zardetto, A. D’Epifanio, S. Pescetelli, F. Matteocci, S. Razza, A. Di Carlo, S. Licoccia, W. M. M. Kessels, M. Creatore and T. M. Brown, Adv. Energy Mater., 2015, 5, 1401808.

145 F. Matteocci, L. Cina, F. Di Giacomo, S. Razza, A. L. Palma, A. Guidobaldi, A. D’Epifanio, S. Licoccia, T. M. Brown and A. Reale, Prog. Photovoltaics, 2016, 24, 436-445.

146 W. Qiu, T. Merckx, M. Jaysankar, C. Masse de la Huerta, L. Rakocevic, W. Zhang, U. W. Paetzold, R. Gehlhaar, L. Froyen, J. Poortmans, D. Cheyns, H. J. Snaith and P. Heremans, Energy Environ. Sci., 2016, 9, 484-489.

147 C.-H. Chiang, J.-W. Lin and C.-G. Wu, J. Mater. Chem. A, 2016, 4, 13525-13533.

148 H.-C. Liao, P. Guo, C.-P. Hsu, M. Lin, B. Wang, L. Zeng, W. Huang, C. M. M. Soe, W.-F. Su, M. J. Bedzyk, M. R. Wasielewski, A. Facchetti, R. P. H. Chang, M. G. Kanatzidis and T. J. Marks, Adv. Energy Mater., 2017, 7, 1601660.

149 C.-H. Chiang, M. K. Nazeeruddin, M. Gratzel and C.-G. Wu, Energy Environ. Sci., 2017, 10, 808-817.

150 A. Agresti, S. Pescetelli, A. L. Palma, A. E. Del Rio Castillo, D. Konios, G. Kakavelakis, S. Razza, L. Cina, E. Kymakis, F. Bonaccorso and A. Di carlo, ACS Energy Lett., 2017, 2, 279-287.

151 G. Fu, L. Hou, Y. Wang, X. Liu, J. Wang, H. Li, Y. Cui, D. Liu, X. Li and S. Yang, Sol. Energy Mater. Sol. Cells, 2017, 165, 36-44.

152 T. Bu, X. Liu, Y. Zhou, J. Yi, X. Huang, L. Luo, J. Xiao, Z. Ku, Y. Peng, F. Huang, Y.-B. Cheng and J. Zhong, Energy Environ. Sci., 2017, 10, 2509-2515.

153 T. Bu, S. Shi, J. Li, Y. Liu, J. Shi, L. Chen, X. Liu, J. Qiu, Z. Ku, Y. Peng, J. Zhong, Y.-B. Cheng and F. Huang, ACS Appl. Mater. Interfaces, 2018, 10, 14922-14929.

154 L. Qiu, Z. Liu, L. K. Ono, Y. Jiang, D.-Y. Son, Z. Hawash, S. He and Y. B. Qi, Adv. Funct. Mater., 2018, 29, 1806779.

155 G. S. Han, J. Kim, S. Bae, S. Han, Y. J. Kim, O. Y. Gong, P. Lee, M. J. Ko and H. S. Jung, ACS Energy Lett., 2019, 1845-1851.

156 E. H. Jung, N. J. Jeon, E. Y. Park, C. S. Moon, T. J. Shin, T.-Y. Yang, J. H. Noh and J. Seo, Nature, 2019, 567, 511-515.

157 T. Bu, J. Li, F. Zheng, W. Chen, X. Wen, Z. Ku, Y. Peng, J. Zhong, Y.-B. Cheng and F. Huang, Nat. Commun., 2018, 9, 4609.

158 S. Razza, F. Di Giacomo, F. Matteocci, L. Cina, A. L. Palma, S. Casaluci, P. Cameron, A. D'Epifanio, S. Licoccia, 
A. Reale, T. M. Brown and A. Di Carlo, J. Power Sources, 2015, 277, 286-291.

159 M. Yang, Z. Li, M. O. Reese, O. G. Reid, D. H. Kim, S. Siol, T. R. Klein, Y. Yan, J. J. Berry, M. F. A. M. van Hest and K. Zhu, Nat. Energy, 2017, 2, 17038.

160 Y. H. Deng, X. P. Zheng, Y. Bai, Q. Wang, J. J. Zhao and J. S. Huang, Nat. Energy, 2018, 3, 560-566.

161 K. Hwang, Y.-S. Jung, Y.-J. Heo, F. H. Scholes, S. E. Watkins, J. Subbiah, D. J. Jones, D.-Y. Kim and D. Vak, Adv. Mater., 2015, 27, 1241-1247.

162 L. Cai, L. Liang, J. Wu, B. Ding, L. Gao and B. Fan, J. Semicond., 2017, 38, 014006.

163 F. Di Giacomo, S. Shanmugam, H. Fledderus, B. J. Bruijnaers, W. J. H. Verhees, M. S. Dorenkamper, S. C. Veenstra, W. Qiu, R. Gehlhaar, T. Merckx, T. Aernouts, R. Andriessen and Y. Galagan, Sol. Energy Mater. Sol. Cells, 2018, 181, 53-59.

164 A. Priyadarshi, L. J. Haur, P. Murray, D. Fu, S. Kulkarni, G. Xing, T. C. Sum, N. Mathews and S. G. Mhaisalkar, Energy Environ. Sci., 2016, 9, 3687-3692.

165 Y. Hu, S. Si, A. Mei, Y. Rong, H. Liu, X. Li and H. Han, Sol. RRL, 2017, 1, 1600019.

166 G. Grancini, C. Roldan-Carmona, I. Zimmermann, E. Mosconi, X. Lee, D. Martineau, S. Narbey, F. Oswald, F. De Angelis, M. Graetzel and M. K. Nazeerudin, Nat. Commun., 2017, 8, 15684.

167 F. De Rossi, J. A. Baker, D. Beynon, K. E. A. Hooper, S. M. P. Meroni, D. Williams, Z. Wei, A. Yasin, C. Charbonneau, E. H. Jewell and T. M. Watson, Adv. Mater. Technol., 2018, 3, 1800156.

168 J. H. Heo, M. H. Lee, M. H. Jang and S. H. Im, J. Mater. Chem. A, 2016, 4, 17636-17642.

169 H. Chen, F. Ye, W. Tang, J. He, M. Yin, Y. Wang, F. Xie, E. Bi, X. Yang, M. Gratzel and L. Han, Nature, 2017, 550, 92-95.

170 Y. Jiang, M. R. Leyden, L. Qiu, S. Wang, L. K. Ono, Z. Wu, E. J. Juarez-Perez and Y. B. Qi, Adv. Funct. Mater., 2018, 28, 1703835.

171 L. Luo, Y. Zhang, N. Chai, X. Deng, J. Zhong, F. Huang, Y. Peng, Z. Ku and Y.-B. Cheng, J. Mater. Chem. A, 2018, 6, 21143-21148.

172 Y. Jiang, M. Remeika, Z. Hu, E. J. Juarez-Perez, L. Qiu, Z. Liu, T. Kim, L. K. Ono, D.-Y. Son, Z. Hawash, M. R. Leyden, Z. Wu, L. Meng, J. Hu and Y. Qi, Adv. Energy Mater., 2019, 9, 1803047.
173 M. R. Leyden, Y. Jiang and Y. B. Qi, J. Mater. Chem. A, 2016, 4, 13125-13132.

174 G. Niu, X. Guo and L. Wang, J. Mater. Chem. A, 2015, 3, 8970-8980.

175 H. S. Kim, J. Y. Seo and N. G. Park, ChemSusChem, 2016, 9, 2528-2540.

176 T. Leijtens, K. Bush, R. Cheacharoen, R. Beal, A. Bowring and M. D. McGehee, J. Mater. Chem. A, 2017, 5, 11483-11500.

177 Y. Yang and J. You, Nature, 2017, 544, 155-156.

178 J. A. Christians, P. Schulz, J. S. Tinkham, T. H. Schloemer, S. P. Harvey, B. J. T. de Villers, A. Sellinger, J. J. Berry and J. M. Luther, Nat. Energy, 2018, 3, 68-74.

179 J. Bauer, J.-M. Wagner, A. Lotnyk, H. Blumtritt, B. Lim, J. Schmidt and O. Breitenstein, Phys. Status Solidi RRL, 2009, 3, 40-42.

180 J. E. Lee, S. Bae, W. Oh, H. Park, S. M. Kim, D. Lee, J. Nam, C. B. Mo, D. Kim, J. Y. Yang, Y. Kang, H.-s. Lee and D. Kim, Prog. Photovoltaics, 2016, 24, 1035-1043.

181 D. Walter, Y. Wu, T. Duong, J. Peng, L. Jiang, K. C. Fong and K. Weber, Adv. Energy Mater., 2017, 8, 1701522.

182 Z. Song, C. L. McElvany, A. B. Phillips, I. Celik, P. W. Krantz, S. C. Watthage, G. K. Liyanage, D. Apul and M. J. Heben, Energy Environ. Sci., 2017, 10, 1297-1305.

183 M. Cai, Y. Wu, H. Chen, X. Yang, Y. Qiang and L. Han, Adv. Sci., 2017, 4, 1600269.

184 N. L. Chang, A. W. Y. Ho-Baillie, P. A. Basore, T. L. Young, R. Evans and R. J. Egan, Prog. Photovoltaics, 2017, 25, 390-405.

185 J. Gong, S. B. Darling and F. You, Energy Environ. Sci., 2015, 8, 1953-1968.

186 M. Kaltenbrunner, G. Adam, E. D. Głowacki, M. Drack, R. Schwödiauer, L. Leonat, D. H. Apaydin, H. Groiss, M. C. Scharber, M. S. White, N. S. Sariciftci and S. Bauer, Nat. Mater., 2015, 14, 1032-1039.

187 Y. Zhao, A. M. Nardes and K. Zhu, Appl. Phys. Lett., 2014, 104, 213906.

188 Y. J. Liou, P. T. Hsiao, L. C. Chen, Y. Y. Chu and H. Teng, J. Phys. Chem. C, 2011, 115, 25580-25589.

189 X. Wang, Z. Lia, W. Xu, S. A. Kulkarni, S. K. Batabyal, S. Zhang, A. Cao and L. H. Wong, Nano Energy, 2015, 11, 728-735.

190 Y. Wu, X. Yang, W. Chen, Y. Yue, M. Cai, F. Xie, E. Bi, A. Islam and L. Han, Nat. Energy, 2016, 1, 16148. 